\title{
地中送電用シールドトンネルの 維持管理に関する研究
}

\author{
塩治 幸男 1 ・阿南 健一2・大塚 正博 3 -小泉 淳4 \\ 1正会員 東京電力(株) 原子力品質監査部（干100-8560 東京都千代田区内幸町1-1-3） \\ E-mail: enya.yukio@tepco.co.jp \\ 2正会員 東電設計(株) 土木本部都市土木部（干110-0015 東京都台東区東上野3-3-3） \\ E-mail: jana@tepsco.co.jp \\ 3フェロー会員＼cjkstart鹿島建設(株) 土木管理本部（干107-8348 東京都港区赤坂6-5-11） \\ E-mail: otsumasa@kajima.com \\ 4正会員 早稲田大学教授 理工学術院社会環境工学科（干169-8555 東京都新宿区大久保3-4-1） \\ E-mail: koizumi@waseda.jp
}

\begin{abstract}
地中送電用シールドトンネルを対象とし，的確な維持管理の方法を検討した。はじめに，現状の点検間 隔やトンネルの健全度などを考慮し，効果的かつ効率的となるように維持管理のサイクルを見直した. 維 持管理サイクルの見直しでは, 経年劣化した継手の健全度や荷重の変動による而荷性能, 点検結果の判定 基準を検討した。継手は, 継手鋼材の腐食速度や継手ボルトの締結力の調査を行い評価した. 変動荷重に よる耐荷性能は, 現状の荷重や今後の変動荷重を推定して評価する方法を示した. また, 従来, 部材の劣 化に着目し経験的に設定されていた点検基準は，性能照査型設計法の考え方を適用し構造計算にもとづく 耐荷性能を主体とした判定基準に見直した。これらの結果から, シールドトンネルの維持管理を合理的に 実施する方法を提案し, 実構造物に適用した。
\end{abstract}

Key Words : shield tunnel, segment, maintenance, Performance-Based Design, load-bearing capacity, beam- spring model

\section{1. はじめに}

東京電力（株）では亘長約478kmの地中送電用トンネ ルのうち，シールドトンネルを約 $252 \mathrm{~km}$ 保有している. 地中送電用シールドトンネルでは，トンネル構造のほか にケーブルなどの電気設備，照明や排水ポンプなどの付 帯設備の点検など，概ね2～3ケ月に1回の頻度で点検が 行われている. これらの点検では, トンネルの異常な漏 水やひび割れなど顕著な変状の有無の確認，ならびに必 要となる緊急的な補修, 補強等も併せて実施している.

トンネル構造に着目した点検は，洞道内部点検と呼ぶ 点検を6年に1回の頻度で実施している．点検間隔は，法 令で定められているケーブルなど電気設備の点検と同時 期に実施するため，同じとしている.

洞道内部点検は洞道内を踏査し，鉄筋の腐食やひび割 れ，漏水などのトンネル変状の有無を目視で確認し，変 状が認められた場合には，必要となる補修，補強などの 対策を実施するものである，すなわち，従来は，いわゆ
る「事後保全」を主とした維持管理となっていた.

一方，地中送電用トンネルは，道路や鉄道，下水道卜 ンネルなどと同様に，高度経済成長期に建設された経年 20〜35年のものが多く ${ }^{1)}$, 将来, 健全度が低下したトン ネルが特定の時期に急増して維持管理に支障が生じるこ とが懸念された。

このような状況から，東京電力（株）では，良質で安 価な電力の安定供給を目指し，維持管理の合理化による 維持管理費の低減と，計画的な維持管理の実施による将 来の維持管理費の平準化を実現することが急務であった.

そこで，本研究では，トンネルの機能に支障を生じな いように予防しながら維持管理を行う「予防保全」を主 にしたシールドトンネルの維持管理手法を確立するため, 鉄筋コンクリート製セグメントによるシールドトンネル を対象とした検討を実施した。

ここで，維持管理を行う場合は，文献2)などから，設 計耐用年数を定めることが必要となる.しかし，特に都 市部の地中構造物は, 而用年数の経過後に再構築する場 


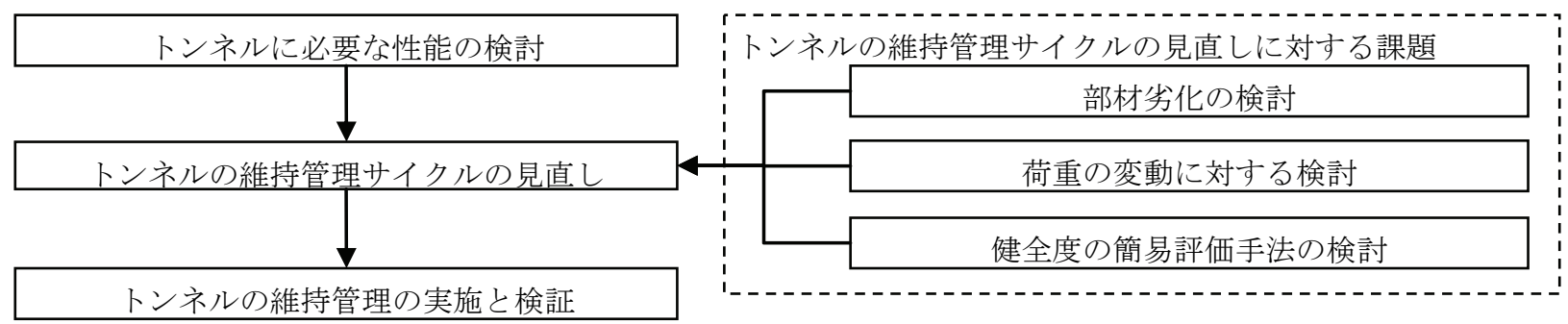

図-1 本研究の検討フロー



(a)部材の劣化

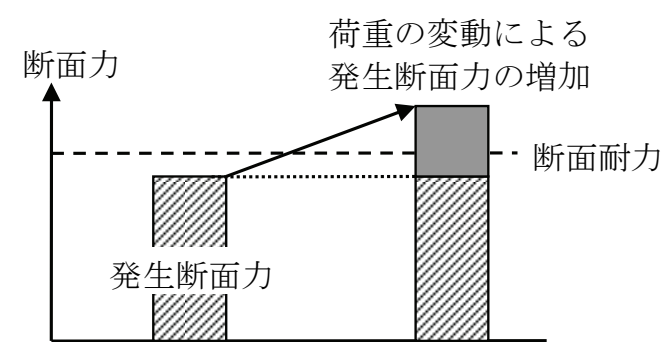

設計荷重 設計荷重十変動荷重

(b)荷重の変動

図-2 而荷性能に問題が生じる要因別の発生断面力と断面耐力の関係の模式図

合，撤去や建設の費用や施工環境などを考えると，使用 期限を定めずに既設の構造物を可能な限り使用すること が要求される場合がある。このため，本研究で設計耐用 年数を明示寸ることが困難であったことから，耐用年数 は定めず，要求性能を満足する維持管理を継続的に実施 する方針として検討を行った.

検討は，図-1に示すフローにより実施した。はじめに， 地中送電用シールドトンネルに必要な性能を整理し，合 理的な維持管理のサイクルについて検討した.

さらに，検討した維持管理のサイクルを適用する場合 の課題を解決するために必要な調查や検討を実施した.

\section{2. 地中送電用シールドトンネルに必要な性能}

地中送電用シールドトンネルは，高圧送電線を収容す る重要構造物として位置付けられている。一方で, 道路 や鉄道トンネルとは異なり第三者が直接トンネルを利用 しないことから，電気設備に支障のない程度の軽微なコ ンクリートのはく離やはく落などの変状は許容できると 考えられる，これより，要求性能（使用性，安全性，環 境性，修䜌性）から，目標性能および構造性能を考える と，次のように整理される334.

1)而荷性能

トンネルの機能（外压耐える）を満足する性能を保 持すること，そのため，鉄筋腐食などによる耐荷性能の 軽微な低下は許容可能.

2)変形性能

送電機能に支障のない範囲の変形は許容可能.
3)而久久性能

送電機能に支障なく而荷性能が担保される範囲の腐食 やコンクリートのはく離は許容可能.

4)止水性能

送電機能への影響や洞道内作業へ支障がなく，かつ土 砂流入に伴う道路陷没などの第三者一の影響を及ぼさな い程度の軽微な漏水は許容可能. ただし，地下水環境一 影響を与えないこと, 漏水に伴う地下水位変化で地盤状 況の変化 (圧密) による荷重の変動が生じないこと.

以上のことから，地中送電用シールドトンネルの最も 重要な性能は耐荷性能であり, 而荷性能を満足する範囲 では鉄筋の腐食やトンネルの変形は許容可能と考えるこ とができる.

通常，維持管理においては，鉄筋の腐食などの部材の 劣化を対象とすることが多い5，わ，一方で，止水性能で 述べたように，近年，軟弱地盤に建設されたトンネルで， 周辺の地下水の変動により荷重が変動し, トンネルの耐 荷性能に問題が生じている事例も報告されている89,9, 10),11) そこで, トンネルの健全度低下の原因として, 部材劣化 と変動荷重の検討が必要と考えた．部材劣化は鉄筋腐食 などにより断面耐力が低下，変動荷重は断面耐力は変わ らないが地盤の状況の変化などにより荷重が変動し発生 断面力が増加することで耐荷性能が低下寸る，と考える ことができる.

これを, 発生断面力と断面耐力の関係として模式的に 示すと図-2のようになる.

これより，本検討は，地中送電用シールドトンネルに 最も重要な耐荷性能にもとづき点検基準などの各検討を 実施することとした．また，耐荷性能の評価では，健全 


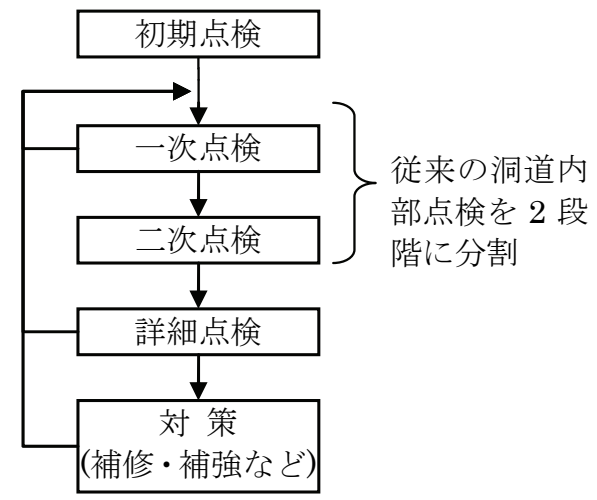

図-3 見直したトンネルの維持管理のサイクル

度の低下要因として部材劣化と荷重変動の2種類を対象 とした。

\section{3. トンネルの維持管理サイクルの検討}

\section{(1) 現状の維持管理のサイクル}

地中送電用シールドトンネルの点検は，竣工後に初期 点検を実施した後，洞道内部点検，詳細点検などの手順 で実施されていた ${ }^{12)}$.

このうち，洞道内部点検は，鉄筋腐食やひひ割れ状況 を目視により観察して記録する，点検結果から，詳細点 検の要否を判定する。このときの判定基淮は，一般的な コンクリート構造物の鉄筋腐食などを対象とした学協会 の基準や指針年を参考に設定されていた。

また，詳細点検は，洞道内部点検で必要と判断された 場合に，コンクリート中の塩化物イオン濃度や中性化深 さなどの調査を目的とした詳細点検を行い補修や補強な どの対策の要否を判定するものである.

\section{（2） 維持管理サイクルの見直し}

洞道内部点検は，6年に1回の頻度で，トンネル内のひ び割れや鉄筋腐食，継手の腐食，漏水の有無と程度を調 査し，調查結果をスケッチ図として記録，ひび割れや鉄 笳腐食量を集約し，詳細点検の要否を判定する。しかし， トンネルには，前回の点検からひび割れなどの変状が進 行しているものがある一方で，変状の進行が認められな い場合も想定される．また，地中送電用シールドトンネ ルは耐荷性能が最も重要であり，鉄筋腐食やひび割れな どが而荷性能に影響を与えるほど急激に進行することは 考えにくい．このため，既往の文献131, 14)なども参考とし て，耐荷性能への影響を考慮し段階的な維持管理サイク ルへの見直しを図ることとした．ここで，点検間隔の見 直しも考えられるが，電気設備の点検なども考慮し，点 検間隔の見直しは行わず，6年間の点検サイクルが劣化 などにより問題が生じないことを確認する方針とした.
土木学会論文集F1 (トンネル工学), Vol. 67, No. 2, 108-125, 2011.

図-3は，見直した維持管理サイクルである。これは，次 のような見直しを行っている.

1)洞道内部点検の見直し

洞道内部点検は，一次点検と二次点検の二段階の点検 とした. このうち，一次点検は，6年に1回の頻度で，初 期点検あるいは前回の二次点検の結果を参照し，ひび割 れの発生や進展，鉄筋腐食範囲の拡大など，変状の進展 に着目し，目視により点検を行う方法とした．そのため， 一次点検は，変状の進展の有無のみを判断するのみの簡 易な点検となる．二次点検は，一次点検で変状の進行が 認められるトンネルのみを対象に，従来の洞道内部点検 と同様の点検方法と同様に，ひび割れや腐食などの進展 や発生を目視により観察するものとした. このため, 変 状の進行が認められないトンネルは，6年ごとに一次点 検を行うサイクルとなる．以上のことから，一次点検で 変状の進展の有無を評価することで，二次点検費用の低 減が期待できる.

2)点検結果の判定基準の見直し

二次点検の結果から詳細点検の要否を判定する基準を 耐荷性能に基づくものに見直す。

以上の見直しにより，必要な耐荷性能を確保しながら， 点検内容を簡素化し，維持管理の合理化を図った。

\section{（3）維持管理サイクルの見直しの課題}

維持管理の合理化のために維持管理のサイクルを見直 すにあたり，以下の事項が課題となった.

1)点検間隔の検証

一次点検の間隔は6年に1回であり，その間に変状が進 行し，健全度が大幅に低下寸ることが䀣念される．多量 の土砂を伴う漏水などの異常については，電気設備など の2〜3ヶ月に1回の点検で発見，対処することが可能で ある. 一方，部材劣化や変動荷重などの進展については， 6年に1回の点検間隔とした場合に問題ないかを確認する 必要がある。

2)評価基準の設定

点検結果から次の段階である詳細点検へ移行するため の判断基準を而荷性能評価に基づいたものに見直寸必要 がある.この際，判定基準は，従来の点検結果を活用す るためにも，ひび割れや鉄筋腐食など従来の点検実施内 容に基づいたものでなければならない，維持管理サイク ルを見直すため，これらの課題に対する検討を行った.

\section{4. 部材劣化の検討}

\section{(1) 現状および課題}

鉄筋コンクリートの鉄筋の腐食は，潜伏期を経て進展 期，加速期，劣化期と進行する ${ }^{16}$ 。鉄筋コンクリート構 


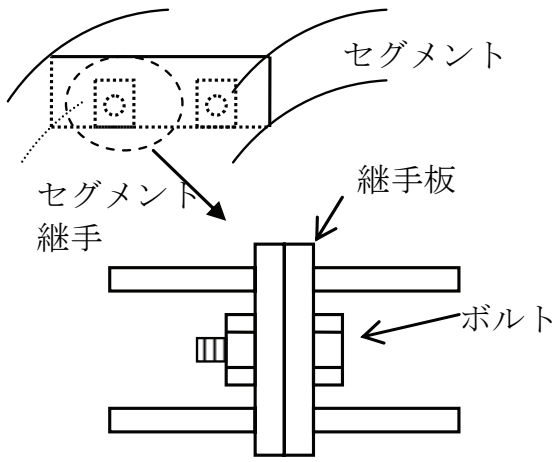

図-4 鋼製ボックスタイプ継手の構造

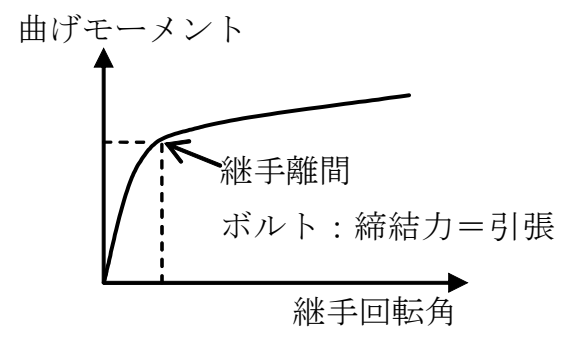

図-5 セグメント継手の変形特性のイメージ

表-1 調査した継手の諸元と数量

\begin{tabular}{|c|c|c|c|c|c|c|c|}
\hline & \multirow{2}{*}{$\begin{array}{c}\text { 経過年 } \\
\text { (年) }\end{array}$} & \multirow{2}{*}{\begin{tabular}{|c|} 
継手板 \\
厚さ $(\mathrm{mm})$ \\
\end{tabular}} & \multirow[t]{2}{*}{ ボルト径 } & \multirow{2}{*}{$\begin{array}{c}\text { 継手閉塞 }{ }^{* 1} \\
\text { の有無 }\end{array}$} & \multirow{2}{*}{$\begin{array}{c}\text { 漏水中の } \\
\text { 塩分 }\end{array}$} & \multicolumn{2}{|c|}{ 調査した継手数 } \\
\hline & & & & & & 継手板厚さ & ボルト調査 ${ }^{*}$ \\
\hline "Tトンネル & 30 & 12,9 & M22 & 有 & 小 & 24 & $16(15)$ \\
\hline Sトンネル & 31 & 12,9 & $\mathrm{M} 24^{* 2}$ & 無 $^{* 3}$ & 小 & 29 & $21(20)$ \\
\hline Nトンネル & 25 & 13,11 & - & 無 & 小 & 12 & - \\
\hline Mトンネル & 24 & 12,9 & M24 & 有 & 大 & 24 & - \\
\hline Kトンネル & 14 & 6 & M20 & 有 & 大 & 5 & - \\
\hline Ks1トンネル & 23 & 19 & M22 & 有 & 大 & 2 & - \\
\hline Ks2トンネル & 21 & 19 & M24 & 有 & 大 & 8 & $8(8)$ \\
\hline & & & & & 合計 & 104 & $45(43)$ \\
\hline
\end{tabular}

*1 : モルタルによる継手のボルトボックスの閉塞，*2：M22のデータを1つ含む

*3 : 簡易な閉塞のため「無」とした, *4 : ( )内はボルトの締結力の調査数

造の劣化原因である中性化や塩化物イオンによる鉄筋腐 食や腐食速度については，本検討で対象とするシールド トンネルに類似した環境にある地中送電用の開削トンネ ルで，腐食に関する調査検討が行われ，腐食速度の傾向 などが把握されていた，そのため，鉄筋の腐食は，6年 に1回程度の点検間隔で而荷性能に大きな影響を与える ような進行はないと考え, 劣化の予測は既往の研究成 果 ${ }^{17}$ に準じて行うこととした.

一方，セグメントの継手に使用されている鋼材は，一 般に，セグメントの組立後にモルタルでボルトボックス を閉塞し，防錆が行われる．しかし，継手個所から漏水 が生じる場合もあるため，コンクリート中の鉄筋と環境 が異なり，継手鋼材の腐食状況については，新たに検討 する必要があった。

そこで, 本研究では, 継手鋼材の腐食に関する検討を 行った.

\section{（2）継手鋼材の調査方法}

\section{a) 調査内容}

継手は，セグメントピースを結合するためのものであ る. 近年は，様々な種類の継手が実用化されているが， 経年30年程度の鉄筋コンクリート製セグメントは，図-4 に示寸鋼製ボックスタイプの継手が多く使われている.

鋼製ボックスタイプ継手は，ボルトの締結によりセグ メントを結合する構造であり, ボルトの引張や継手板の
曲げにより耐荷性能および変形性能が決定する．そのた め，継手板やボルトの腐食量が而何性能に影響すること となる．また，ボルトが緩んでいないことも必要な条件 となる，さらに，曲げによる継手の変形機構は，図-5に 示寸ように継手の離間の前後で継手の変形性能が大きく 変化する.ここで, 継手の離間とは, ボルトの締結力以 上にボルトに引張力が作用して継手板の間が離れた状態 をいう ${ }^{18)}$.これより, 経年シールドトンネルの変形性能 を評価するためには，現状のボルトの締結力，すなわち ボルト軸力の把握も重要と考えた.

このようなことから, 継手板の腐食量, ボルトの腐食 量, ボルトの軸力について調查を実施した.

\section{b) 調査方法}

表-1は，調査を行ったトンネルと継手諸元，調査数量 を示したものである. 継手の調査は以下に示寸手順およ び方法により行った.

1)防錆材料, 錆の除去

モルタルなどの防錆材料を除去し，鋼材の錆をワイヤ ブラシやベルトサンダーなどで除去する.

2)継手板厚さの計測

ボルトを中心に上下左右など6〜12点の継手板の厚さ を超音波肉厚計により計測する。

ボルトの締結力や軸径の計測を実施しない場合は, 計 測後に継手の防錆を行い調査を終了する.

3)ボルトひずみの計測 


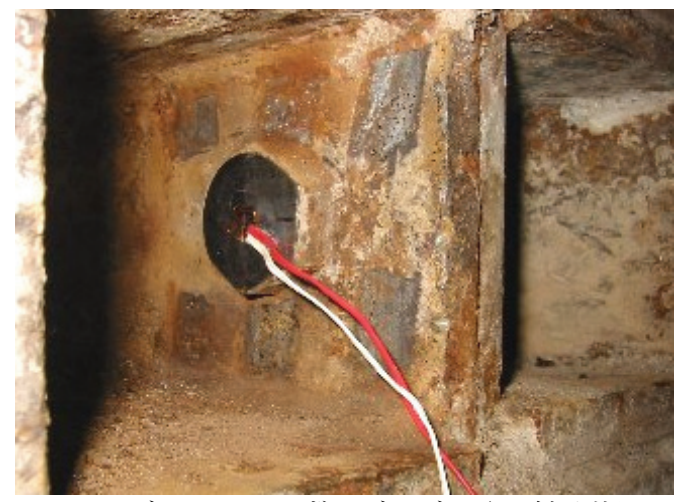

図-6 ボルトへのひずみゲージの取り付け状況

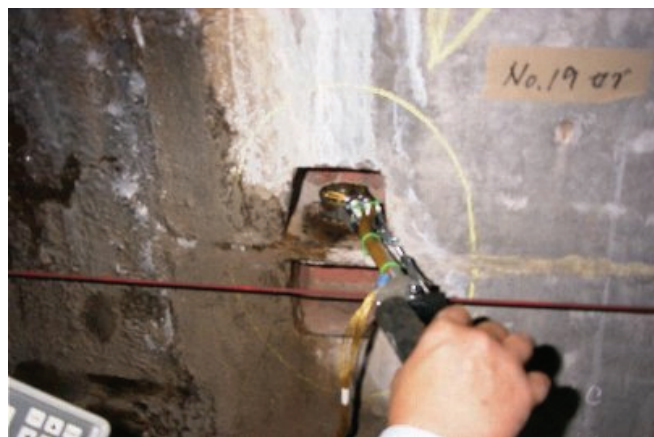

図-7 超音波ボルト軸力計による計測状況

ボルト頭に2軸のひずみゲージを取り付け（図-6）， ひずみの初期值 $\varepsilon_{i}$ を計測する. その後，ボルトを緩め, 再度ひずみ $\varepsilon$ を計測する。 この時のひずみの変動量 $\Delta \varepsilon$ $=\varepsilon$-Eをボルトの軸力に相当するひずみ量とする.

この調査は，ひずみの校正のためボルトの取り外しが 必要となるため, トンネルの耐力に影響する個所の調査 は難しい，そのため，ボルトの取り外しが不要な超音波 ボルト軸力計（図-7）による計測も実施した。 これは, ボルトとナットのねじ部の接触部の超音波透過量がボル 卜軸力による圧力の大小で変化することを応用し，ナッ トの2辺間の超音波速度の変化量からボルト軸力を計測 する方法である. 以後，ボルト軸力の計測方法のうち， ひずみゲージによる方法を「応力解放法」，超音波ボル 卜軸力計による方法を「超音波調査」と呼ぶこととする. なお，応力解放法と超音波検査は，調査前にボルトの 軸力をロードセルと同時に計測する室内試験を実施した。 この結果，応力解放法と超音波検査の結果は，概称良好 な精度を得たが，軸力が小さい場合に超音波検査の結果 がばらついていた。これは，軸力が小さいことで，ねじ 部の圧力も小さく, 超音波透過量がばらつくためであつ た.これより，超音波検査は，軸力が小さい場合など， ねじ部の状態によって，精度が変わるため，注意が必要 である。

\section{4)ボルトの軸径の計測}

ボルトを取外し，直交する2方向のボルト軸径をノギ スで計測する，その後，継手には，同等の径および強度 の新品のボルトを取り付ける.

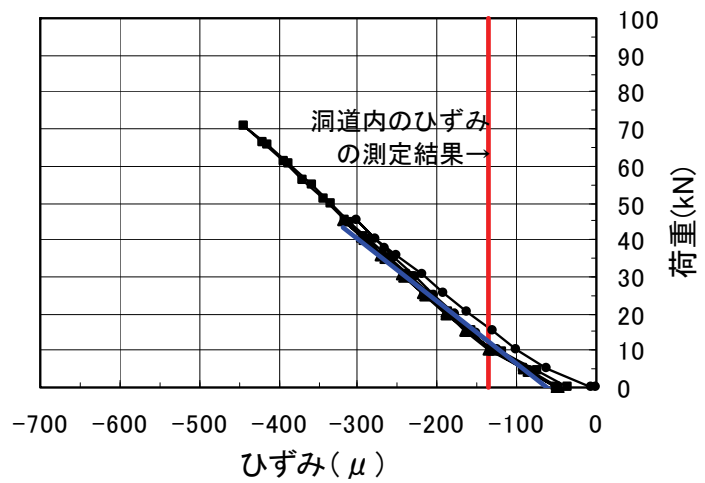

図-8ボルトの引張試験結果の例

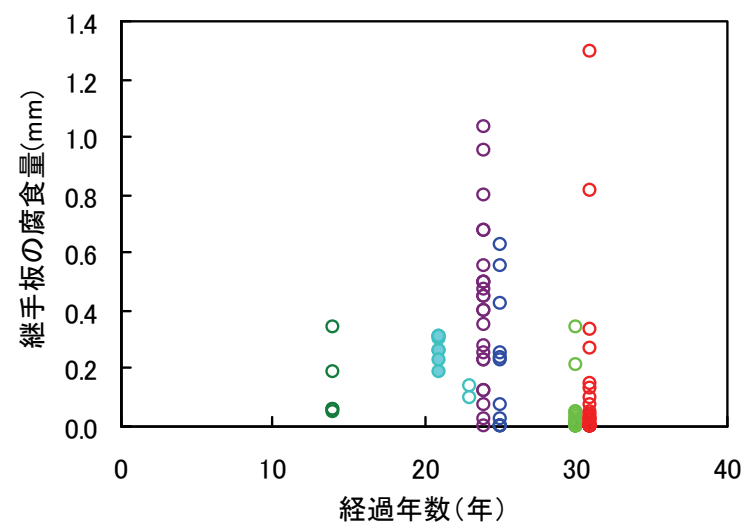

図-9 洞道の経年数と継手板の腐食量の関係

表-2 継手板の腐食量の計測結果

\begin{tabular}{|c|c|c|c|c|c|c|}
\hline & \multirow{2}{*}{$\begin{array}{c}\text { 経過年 } \\
(\text { 年) }\end{array}$} & \multirow{2}{*}{$\begin{array}{c}\text { データ } \\
\text { 数 }\end{array}$} & \multicolumn{2}{|c|}{ 腐食量(mm) } & \multicolumn{2}{|c|}{ 腐食速度(mm/年) } \\
\hline & & & 平均値 & 最大値 & 平均値 & 最大値 \\
\hline Tトン & 30 & 24 & 0.033 & 1.600 & 0.001 & 0.053 \\
\hline 卜ン & 31 & 29 & 0.117 & 5.000 & 0.004 & 0.161 \\
\hline N卜 & 2 & 12 & 0.201 & 1.500 & 0.008 & 0.060 \\
\hline Mト & 24 & 24 & 0.418 & 1.900 & 0.017 & 0.079 \\
\hline K卜ン & 14 & 5 & 0.140 & 0.800 & 0.010 & 0.057 \\
\hline Ks1トンネル & 23 & 2 & 0.119 & 0.500 & 0.005 & 0.022 \\
\hline Ks2トンネル & 21 & 8 & 0.272 & 0.500 & 0.013 & 0.024 \\
\hline 全デー & & 104 & 0.190 & 5.000 & 0.008 & 0.16 \\
\hline
\end{tabular}

\section{5)継手の防錆}

継手板に防錆材を塗布した後に，無収縮モルタルにて ボルトボックスの閉塞を行う.

6)ボルト軸力の算定

忘力解放法は，試験室で取り外したボルトの引張試験 を行い，引張力とひずみとの関係を計測する．載荷は， 3回の繰返しにより行い，1,2回目はボルトの許容応力度 の80\%程度，3回目はボルトの降伏応力度の $80 \%$ 程度まで 載荷した．ボルトの軸力とひずみの関係は，図-8に示す ように線形関係となり，3回の載荷のばらつきも少なか

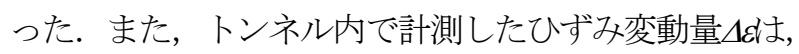
ほとんどがボルトの許容応力度の $80 \%$ に相当するひずみ 量以下となっていた。これらのことから，2回目の載荷 によるボルト軸力とひずみ量との回帰直線の公配を校正 係数 $k$ とし，トンネル内で計測したひずみの変動量 $\Delta \varepsilon に$ 


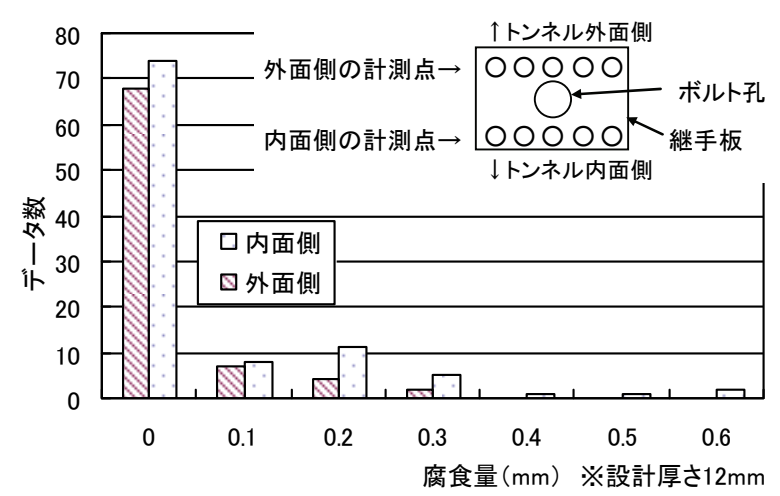

図-10＼cjkstart継手板の計測位置による腐食の例

校正係数 $k$ を乗じてボルトの軸力を評価した.

\section{(3) 継手鋼材の調査結果}

\section{a) 継手板の調査結果}

図-9は経年数と腐食量の関係を，また，表-2は計測結 果をトンネルごとに集約した結果を示したものである. 一部のデータで腐食量が大きく, 最大で $5 \mathrm{~mm}$ というデ 一タが見られる。これは，1個所の継手で数点計測した うちの一部のデータであり，設計図書などから継手板背 面のシール溝などの影響によるものと思われる。それ以 外の腐食量の平均值は $1 \mathrm{~mm}$ 未満となっている. 図-10は, 継手板のトンネルの外面側および内面側の位置と腐食量 を比較した例として，モルタルによる継手の閉塞が行わ れていたTトンネルの結果を示したものである. トンネ ル内面側の方が腐食量が大きくなるような傾向も見られ るが，全データ数に比べるとその差は少ないことから， 本研究によるデータから, 継手板の位置による腐食の傾 向は得られなかった. また, 漏水個所と腐食量との相関 についても分析を試みたが明確な傾向は得られなかった. 継手のモルタルは，トンネル内の温度変化などによりひ び割れが生じやすい，そのため，モルタル閉塞による継 手板の防錆効果は，コンクリート中の不動態皮膜ほどの 防錆効果は期待できないものの，水分や酸素の供給をあ る程度制限して継手板の腐食を抑制する効果があると考 えた，そこで，継手板の腐食は計測結果の平均值で評価 し，それを竣工時からの経年数で除した腐食速度として 評価した.

その結果，腐食速度は平均 $0.001 \sim 0.017 \mathrm{~mm} /$ 年となった. また，各トンネルにおける継手の環境条件を，モルタル による継手閉塞の有無, 漏水中の塩分量（塩化物イオン 濃度）により，以下の3つに分類すると次のようになる. 1)継手モルタル閉塞, 漏水の塩化物イオン濃度小

腐食速度 $0.001 \mathrm{~mm} /$ 年

2)継手閉塞なし，漏水の塩化物イオン濃度小

腐食速度 $0.004,0.008 \mathrm{~mm} /$ 年

3)継手モルタル閉塞, 漏水の塩化物イオン濃度大
表-3 ボルト軸径の腐食量の計測結果

\begin{tabular}{|c|c|c|c|c|c|c|}
\hline & \multirow{2}{*}{\begin{tabular}{|c|} 
経過年 \\
(年)
\end{tabular}} & \multirow{2}{*}{$\begin{array}{c}\text { データ } \\
\text { 数 }\end{array}$} & \multicolumn{2}{|c|}{ 腐食量(mm) } & \multicolumn{2}{|c|}{ 腐食速度(mm/年) } \\
\hline & & & 平均値 & 最大値 & 平均値 & 最大値 \\
\hline T下 & 30 & 16 & 0.153 & 0.700 & 0.005 & 0.023 \\
\hline Sトンネル & 31 & 21 & 0.262 & 1.600 & 0.008 & 0.052 \\
\hline Ks2トンネル & 21 & 8 & 0.109 & 0.275 & 0.005 & 0.013 \\
\hline 全データ & & 45 & 0.196 & 1.600 & 0.007 & 0.052 \\
\hline
\end{tabular}

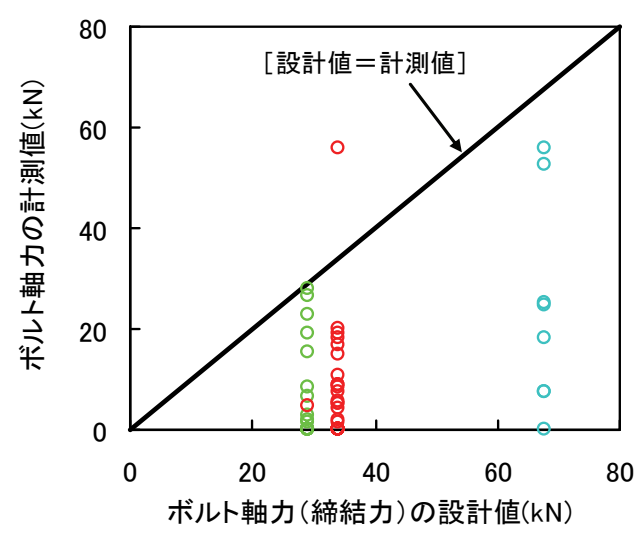

図-11 ボルト軸力の設計值と計測值との関係

\section{腐食速度 $\quad 0.005,0.010,0.013,0.017 \mathrm{~mm} /$ 年}

これより，漏水中の塩化物イオン濃度が大きくなると 腐食速度が大きくなる傾向が明らかとなった．また，継 手の閉塞の有無によっても腐食速度が変わる傾向も得ら れた. この結果から, 最大の腐食速度 $0.017 \mathrm{~mm} /$ 年とした 場合，点検間隔の6年で $0.1 \mathrm{~mm}$ 程度の腐食量となり，継 手板厚さを $9 \mathrm{~mm}$ としも, 減少量はわずか $1 \%$ 程度であ る. そのため，点検間隔の6年では，トンネルの耐荷性 能へ与える影響は少ないと判断した.

本研究による腐食速度は，標準化を図るために十分な データ数に基づくものとは言えないが，トンネルの耐荷 性能を評価するうえでの有効な指標となると思われる.

\section{b) ボルト軸径の調査結果}

表-3は，計測結果を示したものである．表-1に示した 各トンネルの継手閉塞や漏水中の塩分の環境条件と腐食 量を対比すると, 最も腐食速度が大きいSトンネルの漏 水中の塩分が少ないなど, 継手板のように環境条件によ る腐食速度の違いを明確にすることができなかった。

継手の耐荷性能は，通常，ボルトより継手板の而荷性 能で決定する，そのため，一般的には，継手板の腐食量 で評価すればボルトの腐食は問題ないと考え, 点検間隔 を6年とすることに問題はないと判断した．しかし，一 部のデータでボルトの腐食が大きくなっていることから， 継手の腐食が顕著なトンネルで詳細点検および而渮性能 を評価する場合には，ボルト軸部の腐食量を調査し，腐 食によるボルトの破断も検討する必要がある.

\section{c) ボルト軸力の調査結果}

図-11は，応力解放法によるボルト軸力の調査結果を 示したものである. 東京電力（株）における施工時のボ 


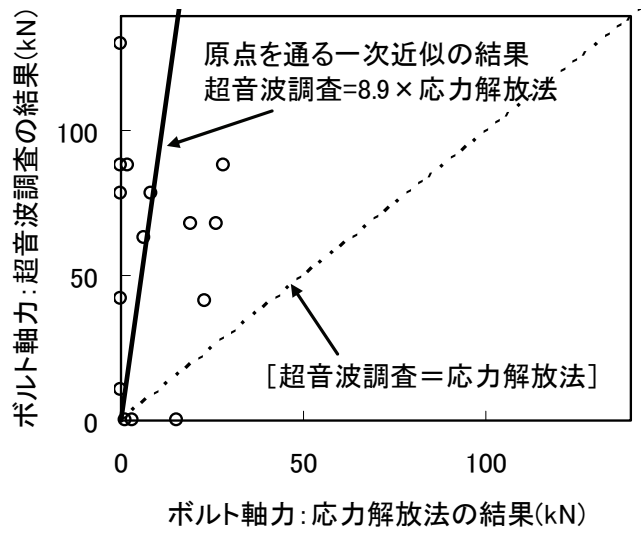

(a)Tトンネルの結果

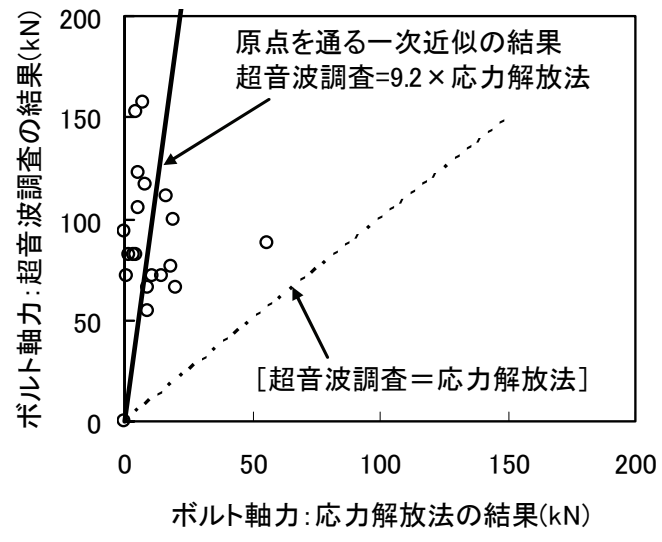

(b)Sトンネルの結果

図-12 ボルト軸力の測定方法による比較

ルトの締結力の目安は，許容応力度の80\%程度としてい る. そのため, 竣工当時のボルトの許容応力度の $80 \%$ と なる軸力を設計值として，計測結果のボルト軸力を評価 した．この結果，設計值を超えるのは1データのみであ り，これ以外は，設計值以下であった．また，ほとんど 軸力が発生していないデータもあり，ばらつきが非常に 大きくなった．得られたデータは，0付近に多く分布し ていることから，対数分布と仮定し平均值を算出すると， 設計值に対し6\%程度と非常に小さな值となる。これよ り, 経年30年程度のシールドトンネルでは, 継手ボルト の軸力は耐力評価上ほとんど期待できないと考えられる. この理由としては，調査対象のトンネルの竣工時に用い られていたシール材のブチルゴムがボルト締付けにより 塑性化して締付力が低下寸ることや，土水圧などの設計 荷重の作用によりセグメントに断面力が生じることによ るコンクリートのクリープ変形やボルト鋼材のリラクゼ ーションの影響などが考えられる.

図-12は，応力解放法と超音波調査の結果の相関を示 したものである．超音波調査は応力解放法より大きな結 果を与える傾向にある。これを超音波調査に対する応力 解放法の結果の相関として整理すると，超音波調查結果 は，応力解放法の約9倍程度となっている。この原因と しては, 超音波調査の主な計測対象は降伏応力度程度で 許容応力度以下では精度が低下寸る傾向にあることが考 えられる．これは，室内試験による両計測方法の比較で も確認された. さらに，トンネル内のボルトはボルトと ナットの間の腐食生成物などにより超音波の伝達速度が 高くなり，それが計測結果に影響していることなども考 えられた。一方，超音波調查は，トンネルの安全性確保 からボルトの取り外しが困難な個所の調査も可能との長 所を有している. そのため, 応力解放法と超音波調查を 併用することで，ボルトの取り外しが困難な個所のボル 卜軸力を精度良く評価することが可能になると考えられ る.

\section{(4) 継手鋼材の調査結果のまとめ}

継手鋼材に関する調査結果をまとめると以下のとおり となる。

1)継手板の腐食

6年に1回の点検でも，腐食により耐荷性能に問題が生 じることはない．また，モルタルによる継手の閉塞の有 無と漏水の塩化物イオン濃度の大小により腐食速度の傾 向を把握することができた.

2)ボルトの腐食

通常はボルトの腐食は問題ないが，腐食が著しく進行 していると見られる場合は詳細な調査検討が必要である. 3)ボルトの軸力

経年シールドトンネルの継手ボルトの軸力は耐力評価 上ほとんど期待できない．なお，ボル卜軸力計測精度を 向上するためには, 応力開放法と超音波調查を併用寸る ことが有効と考えられる。

\section{5. 荷重の変動に対する検討}

\section{(1) 現状と課題}

シールドトンネルの主な設計荷重は土水圧荷重である. 土水圧荷重の設定には，地盤条件や地下水位の変動など の不確定要素を含むことから, 荷重の変動が大きなリス クとして考えられる.

東京電力（株）においても，軟弱な粘性土地盤に建設 されたシールドトンネルの一部で，変動荷重によると思 われるトンネル断面の横潰れ変形とそれに伴うトンネル 軸方向のひび割れが認められている ${ }^{8) 9,10)}$.ここで, 軟弱 地盤における変動荷重は以下のように説明される．地下 水の汲み上げやトンネル内への漏水に伴う圧密沈下によ りトンネル周辺地盤の体積が減少し，強固なトンネル構 造物と地盤の間に生じる相対変位により，トンネルに作 用する鉛直荷重が変動する．これは，Marston-Spanglerの 理論8),9)と同様のメカニズムとなっている. 


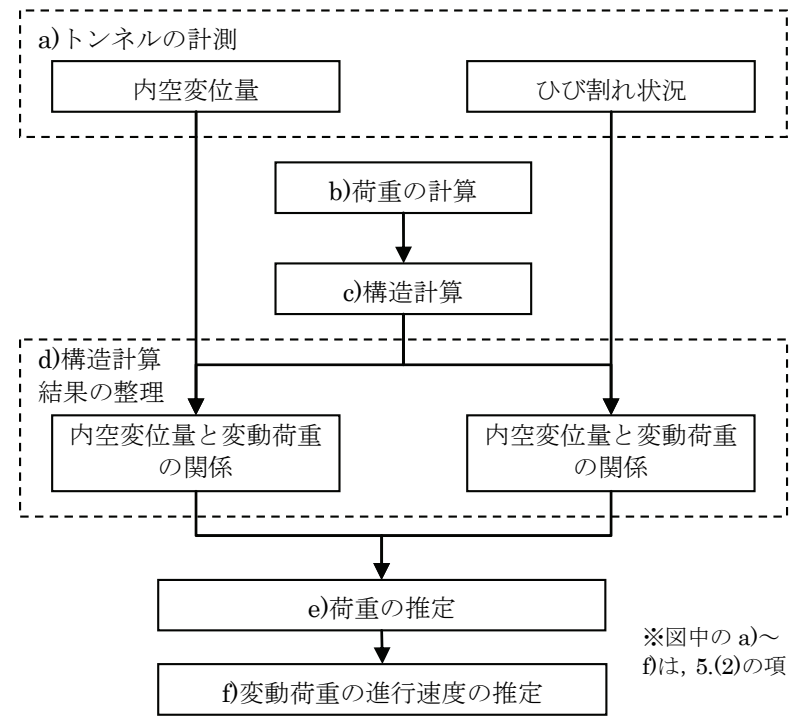

図-13 トンネルに作用する荷重の推定手順

本研究では，変動荷重のリスクとして軟弱粘性土地盤 の圧密による変動荷重を対象として，トンネル内の点検 結果から, 現状の荷重状態と将来の荷重状態を推定し, 而荷性能を評価し，点検間隔について検討した.

\section{（2）荷重の推定方法}

既設のトンネルに作用している荷重を直接計測するこ とが望ましいが，現在の技術では困難である，そこで， トンネル内で計測可能な項目と構造計算から，荷重を推 定する方法を検討した.

ここで，荷重の推定は，次の仮定により行っている. 1)設計荷重を初期荷重とする.

2)変動荷重は，トンネル周辺の地下水変動状況をモデル 化した土/水連成の2次元FEM解析により算出する.

3)変動荷重は，最大の荷重值に対し，鉛直方向と水平方 向が同時に変動する.

4)変動荷重の初期段階は，荷重の変動量と時間が比例関 係にある。

これにより，荷重の推定は以下に示す手順により実施 する．荷重の推定手順をフロー眓にしたものが図-13で ある。

\section{a) トンネルの計測}

変動荷重を推定するため内空変位量とひび割れ状況に 着目した計測を行う。内空変位量は，レーザー距離計を 用いて，鉛直および水平方向のトンネル内径を計測し， 真円に対する変形量を算定する(図-14).

ひび割れ状況は，構造計算による検討実績や現場の状 況から，トンネル天端付近のトンネル軸方向のひび割れ 本数に着目し，計測を行う. 計測結果は，1リング当た りのひび割れ本数として整理する.

\section{b) 荷重の計算}

シールドトンネルには，文献8), 9), 10), 19)に示されて

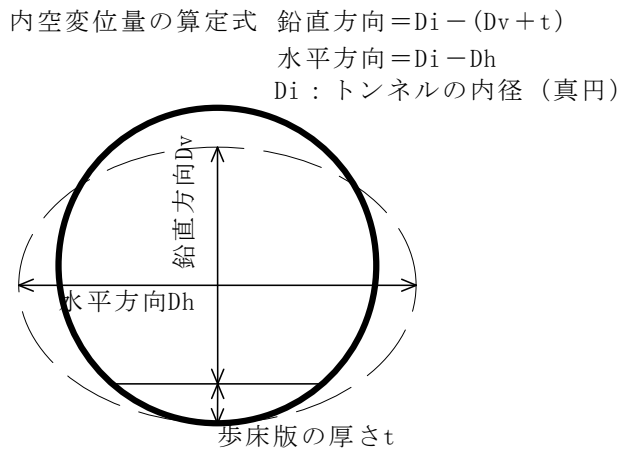

図-14 トンネルの内空変位量の計測位置と算定方法

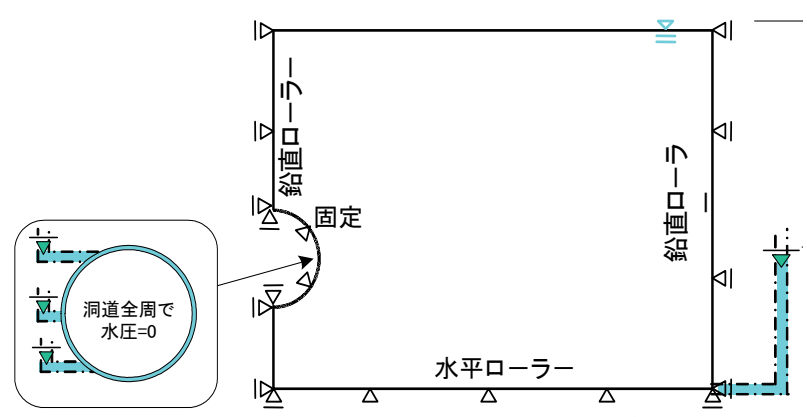

図-15＼cjkstart地下水位の変動による変動荷重の計算モデル

表-4 土水連成FEMによる変動荷重の算定結果

\begin{tabular}{|l|r|r|}
\hline \multirow{2}{*}{} & \multicolumn{2}{|c|}{ 設計荷重に対する比 } \\
\cline { 2 - 3 } & 鉛直荷重 & 水平荷重 \\
\hline Mトンネル & 0.30 & -0.16 \\
\hline Ks1トンネル & 0.40 & -0.18 \\
\hline Ks2トンネル & 0.34 & -0.15 \\
\hline Keトンネル & 0.30 & -0.13 \\
\hline
\end{tabular}

いるように，トンネル内の漏水や広域的な地下水位低下 に伴う圧密による変動荷重が生じている事例が見られる。 検討に用いる荷重は，設計荷重と変動荷重とに分けて 設定した. 設計荷重は，圧密などによる変動荷重が生じ ない場合の荷重として，文献18)などと同様に算定した。 検討事例は，全て軟弱地盤に建設されたトンネルである ことから，全土被り圧荷重，土水一体として設定した。

変動荷重は, 設計荷重からの変動量とし,トンネル周 辺の地下水変動状況をモデル化した土/水連成の2次元 FEM解析（プログラムコード : DACSAR) $)^{8)}$, 19)により算出 した．図-15は，本研究で用いた計算モデルの例である. 地下水は，トンネルの地下水位の観測結果などの状況に 応じて，広域的な地下水位低下やトンネル内の漏水をモ デル化し，地下水の変動によるトンネル荷重の変動を算 定した。広域的な地下水低下は，境界条件として低下し た水位を与え，地下水が定常状態となるまでの計算を行 った. トンネル内の漏水の場合は，トンネル内面を全て 排水条件（水圧を0）とし，継続的に漏水が生じている として，地下水が定常状態になるまで計算を行った.

計算結果を表-4に示す，Mトンネル，Ks1トンネル， Ks2トンネルは，トンネル内の漏水による地下水位変動, 


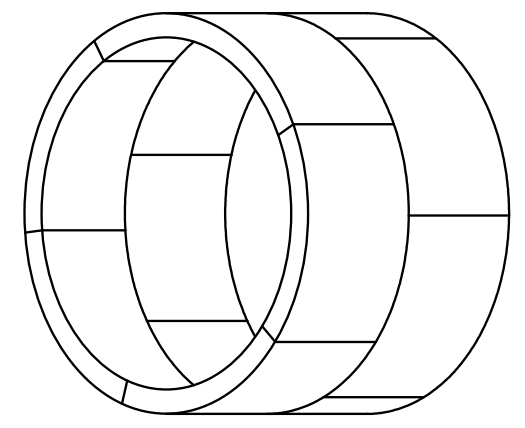

(a)セグメントの組立状況

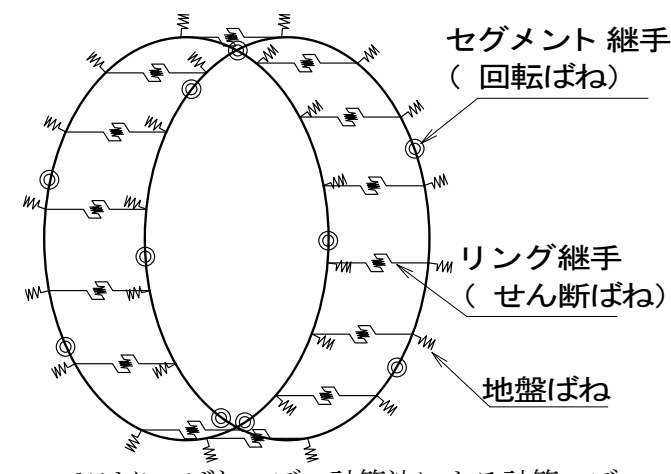

(b)はりーばねモデル計算法による計算モデル

図-16 セグメントの構造計算モデル

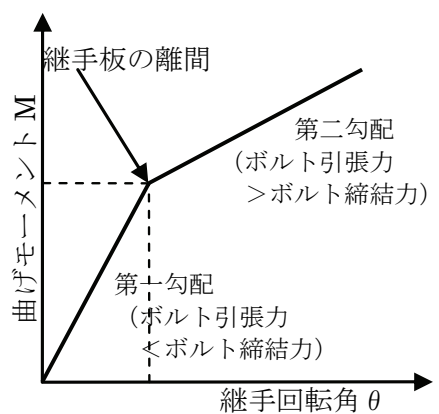

図-17 セグメント継手の部材モデル

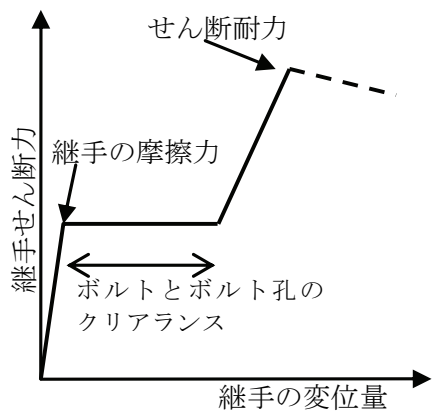

図-18 リング継手の部材モデル
Keトンネルは広域的な地下水位低下とトンネル内の漏 水の両方による地下水変動をモデル化して計算した.

\section{c) 構造計算}

構造計算は，図-16に示すセグメントの継手構造およ び各部材の非線形性を考慮したはりーばねモデル計算法 により行う。はりーばねモデル計算法は, 以下に示すよ うなモデル化を行い，シールドトンネルの変形や応力状 態を精度良く計算できる方法であり，現場計測結果と比 較するに適した計算方法となっている33.4.

1)計算モデル

はりーばねモデル計算法は，セグメント本体をはり要 素，セグメント継手を回転ばね要素，リング継手をせん 断ばね要素, セグメントと地盤の相互作用を地盤ばねと してモデル化した方法である.さらに，シールドトンネ ルで一般的に行われる千鳥組（セグメント継手がトンネ ル軸方向に連続しないように組み立てる方法）を図-16 に示したように 2 リング周期でセグメント本体やセグメ ント継手を配置し，トンネル軸方向の3次元性をモデル 化している.

非線形の収束計算は，荷重の分割を200とした荷重増 分法により実施した.

2)非線形性モデル

セグメント主断面（セグメント本体）はBronsonによ る剛性低下モデル4,22)を用いた。

セグメント継手は，村上，小泉によるモデル ${ }^{18}$ を用い た．村上，小泉によるモデルは，セグメント継手の挙動 を図-17のように，継手に作用する曲げモーメントと回
転角の関係として，回転ばね定数を設定する，回転ばね 定数は, セグメント継手の構造から, 曲げの方向により 異なる剛性で，バイリニアの関係としている. バイリニ ア関係は，継手に作用する曲げモーメントによるボルト の引張り力が，ボルトの締結力以下で継手板が接してい る状態の第一勾配（離間前），ボルトの締結力以上で継 手板が離れている状態の第二勾配（離間後）となってい る. 本検討では, 文献4)から, 継手曲げ試験のデータ （正曲げ12，負曲げ7）の結果と比較し，実験と整合す るように第二勾配の回転ばね定数に対する補正係数（正 曲げ0.32，負曲げ0.56）を用いた。 また，先のボルト調 查から既設シールドトンネルのボルトの締結力が非常に 小さく, ボルトの締結力は期待できないとして, ボルト の引張力がボルト締結力以下となる第一勾配は無視し, 第二勾配のみのリニアモデルとした.

リング継手は, 継手の摩擦力やボルトとボルト孔のク リアランス量から設定される, 吉本らによるトリリニア モデル4を用いた（図-18）。

地盤ばねは，セグメントが圧縮力を受ける場合に作用 し，引張力を受ける場合には作用しないばねとして，文 献23)に示されているモデルを用いた.

3)計算ステップ

構造計算は, step1:セグメント自重の計算, step2:設計 荷重の計算, step3:変動荷重の計算, として実施した

（図-19）。step2，3は，前ステップの計算結果を初期值 としたステップ計算としている．また， step3は，設計荷 重から変動荷重の終了までの, 荷重の変動過程の結果を 


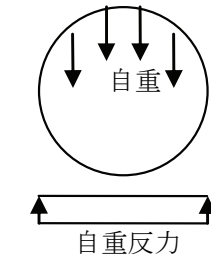

step1

セグメント自重の計算

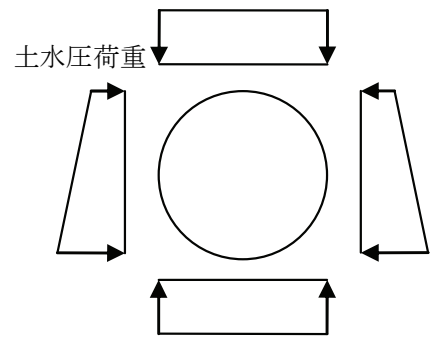

step2 設計荷重の計算

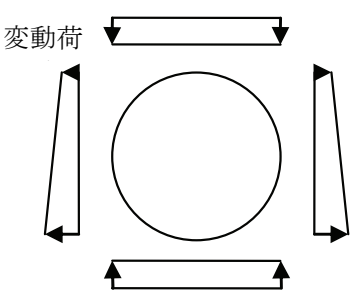

step3 変動荷重の計算

図-19 構造計算の計算ステップ

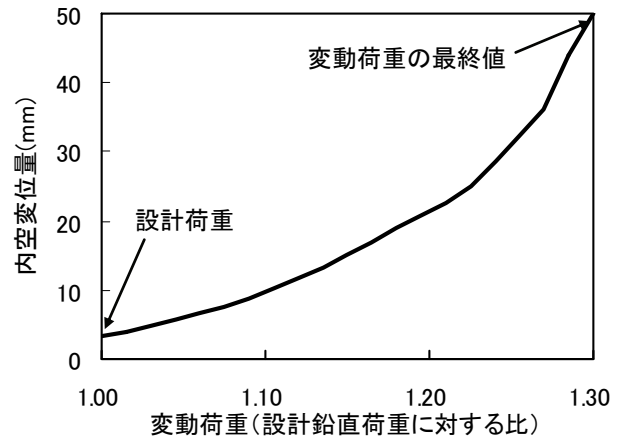

図-20 変動荷重と内空変位量の関係の例（Mトンネル）

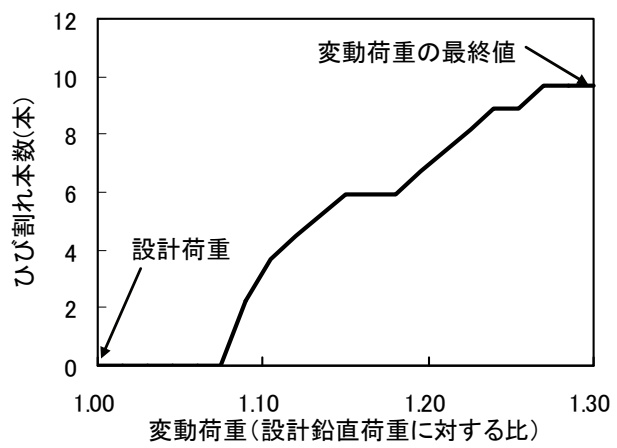

図-21 変動荷重とひび割れ本数の関係の例（Mトンネル）

出力し, 変動荷重と変形量や断面力の関係を検討した.

\section{d) 構造計算結果の整理}

計算結果は，図-20や図-21に示寸ように「変動荷重一 内空変位量」,「変動荷重一ひび割れ本数」の関係とし て整理した.

計算結果から内空変位量は，トンネル上下端や左右端 の節点の相対変位量として算定される．また，ひび割れ 本数は，トンネル天端付近のひび割れを対象とし，セグ メントが配力筋間隔でひび割れが発生するとの特性4, 24) から次のように算定した.

1)トンネル天端部の正曲げとなる全要素について，発生 断面力から，文献21)のひび割れ幅算定式を用いてひび 割れ幅を算定する. トンネル天端を対象とするのは，ひ び割れが発生するトンネル内面が引張りとなる正曲げは, トンネル天端または下端付近であり，さらにトンネル下 端は歩床版があり点検できないためである.

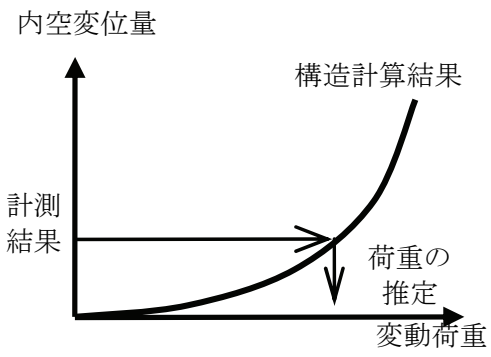

図-22 内空変位量の計測結果からの変動荷重の推定方法

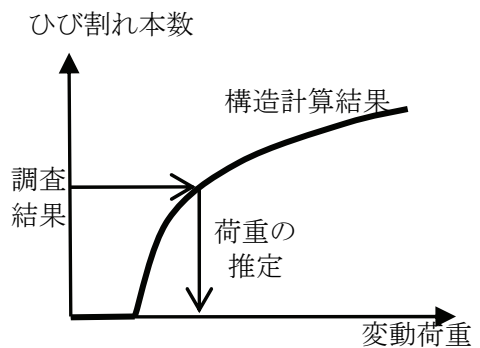

図-23 ひび割れ本数の調査結果からの変動荷重の推定方法

2)二次点検で対象とする幅0.1mm以上のひび割れとなる 要素数nを集計する.

3)集計した要素数nに1要素の長さを乗じて，幅0.1mm以 上のひび割れが発生しているトンネル円周上の範囲 $w$ を 算定する $(w=n \times l)$.

4)ひび割れ発生の範囲 $w$ を配力筋間隔 $w_{s}$ で除して，ひび 割れ本数とする $\left(=w / w_{s}\right)$.

\section{e) 荷重の推定}

調査結果の内空変位量, ひび割れ本数から, トンネル に作用している変動荷重の大きさを推定する.

図-22や図-23に示すように，構造計算結果を整理した 「変動荷重一内空変位量」と「変動荷重一ひび割れ本 数」の関係を用いて, 調査結果の内空変位量やひび割れ 本数に相当する変動荷重の大きさを算定する.これを, トンネル軸方向の点検データについて整理すると，トン ネル軸方向の変動荷重の分布が得られる.

\section{f) 変動荷重の進行速度の推定}

維持管理では，将来の状態を予測し，対策を検討する ことも重要である，そこで，推定した変動荷重から，将 


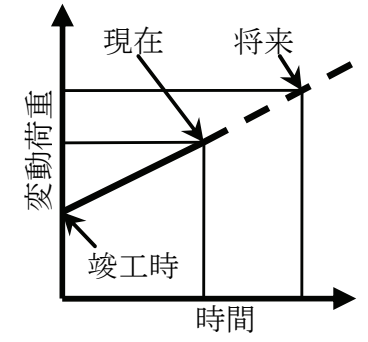

図-24変動荷重の将来予測のイメージ

来の変動荷重の大きさを推定することとした.

将来の変動荷重の推定は，竣工時は設計荷重が作用し， 変動荷重は時間に比例すると仮定して行った。 これより, 将来の変動荷重の大きさは, 図-24に示すように, 現在 までの荷重の変動速度が「現在の変動荷重：現在の経年 数」となり, 将来の変動荷重の大きさが「現在までの荷 重の変動速度×将来の経年数」として算定される.

\section{（3）荷重の推定結果}

\section{a) 検討事例}

荷重の推定は，表-5に示寸軟弱地盤中に建設され変形 が進行していると考えられるトンネルに対して行った. いずれもN值が 0 ～1程度の軟弱地盤に建設され，竣工か ら20年以上が経過し，図-25のようにトンネル天端部分 に多くのトンネル軸方向ひび割れが見られる.

\section{b) 検討結果}

内空変位量およびひび割れからの荷重の推定結果を 図-26〜図-30に示す。結果は，トンネル軸方向の位置 （リングNo.）と鉛直方向の設計荷重に対する変動荷重 の比との関係として整理している．Mトンネルでは，ト ンネル内の設備が支障となりレーザー距離計による計測 を実施することができなかった，そのため，1/500mmの 変位が計測可能なマイクロクリープメーターによる9年 間の計測結果から内空変位の進行速度を設定し, 経年数 と内空変位の進行速度の積から内空変位量を推定した.

この結果から，次のような傾向が見られる.

1)ひび割れ本数と内空変位量からの荷重の推定結果は, 同程度となっている.

2)ひび割れ本数より内空変位量の方が荷重を大きく評価 する傾向にある.この原因として，竣工時に生じていた 施工誤差による変形量を考慮できないため内径計測結果 が大きく評価されることが考えられる.

3)Keトンネルの20６0リング付近は，荷重の推定結果が 大きく異なっている．この区間では，幅0.5mm以上のひ び割れが多く見られている，一方，構造計算では，ひび 割れ幅が0.35mm程度となる時，トンネル天端付近の正 曲げの範囲の全体にひび割れが生じ，これ以上ひび割れ の範囲が拡大しない，そのため，ひび割れによる荷重の 推定の適用範囲を超えていることが原因となっている.

表-5 変動荷重の推定の検討厅ース

\begin{tabular}{|l|c|c|c|c|}
\hline \multirow{2}{*}{} & 内径 & \multicolumn{2}{|c|}{ セグメント } & 竣工年 \\
\cline { 3 - 4 } & & 厚さ & 分割数 & \\
\hline Mトンネル & $3.5 \mathrm{~m}$ & $0.25 \mathrm{~m}$ & 6分割 & 1980 \\
\hline Ks1トンネル & $3.7 \mathrm{~m}$ & $0.25 \mathrm{~m}$ & 6分割 & 1980 \\
\hline Ks2トンネル & $3.7 \mathrm{~m}$ & $0.25 \mathrm{~m}$ & 6分割 & 1982 \\
\hline Keトンネル & $5.05 \mathrm{~m}$ & $0.30 \mathrm{~m}$ & 6分割 & 1983 \\
\hline
\end{tabular}

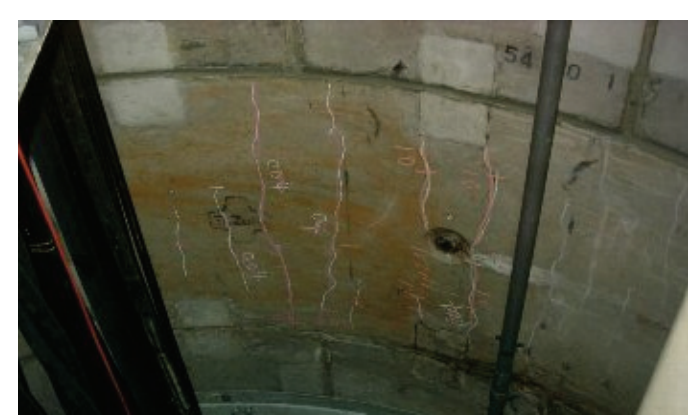

図-25Ｍトンネルの天端付近のひび割れ状況

以上のことから，内空変位量およびひび割れからの荷 重の推定は，現状の而荷性能の評価に用いることが可能 と判断した.この結果から推定した荷重状態に対して, 構造計算を実施し，トンネルの耐荷性能を評価すること ができる.

ただし，計測の誤差などを含むことから，維持管理を 行う場合は，本方法により現状の荷重を推定し，耐荷性 能に問題があると判断された場合，而何性能の余裕の程 度に応じた対策を実施する方針とした。

而荷性能に余裕があり，数mmの内空変位量の増加が 許容可能な場合には，簡易な計測機器（誤差士 $1.5 \mathrm{~mm}$ 程 度のレーザー距離計）により1年に1回程度の内径計測と ひび割れ本数の増加を確認し，変動荷重の有無や程度を 把握する.

而荷性能に余裕がない場合は，高精度の計器を用いた 内空変位量の計測やひび割れ本数の継続調査などにより, 短期間で変状の進行程度を把握し，必要に応じて補強な どの対策の検討を行う.

\section{c）変動荷重の進行速度の検討}

点検間隔の評価および将来の予測による維持管理計画 の立案のため, 荷重の変動速度の推定方法を検討した.

図-31に示すように，現在，推定される変動荷重の大 きさは，土/水連成FEM解析や遠心載荷試験の結果 ${ }^{83) 99,19) 力 ~}$ ら, 経過時間と変動荷重が線形関係に近くなっている. 補修や補強の対策を含め維持管理は，トンネルに必要な 性能を維持するため, 図-31の線形関係と考えられる範 囲で実施する．さらに，経過時間と変動荷重を線形関係 とすることで, 将来の荷重を大きく推定する傾向となり 安全側の評価となる。また，図-32に示すように，Mト ンネルでの9年間の内空変位計測の実績からも，変形は 一定の割合で進行し，時間と変位量は線形関係にあると 考えられる．ここで，図-32の変位が周期的に変動して 


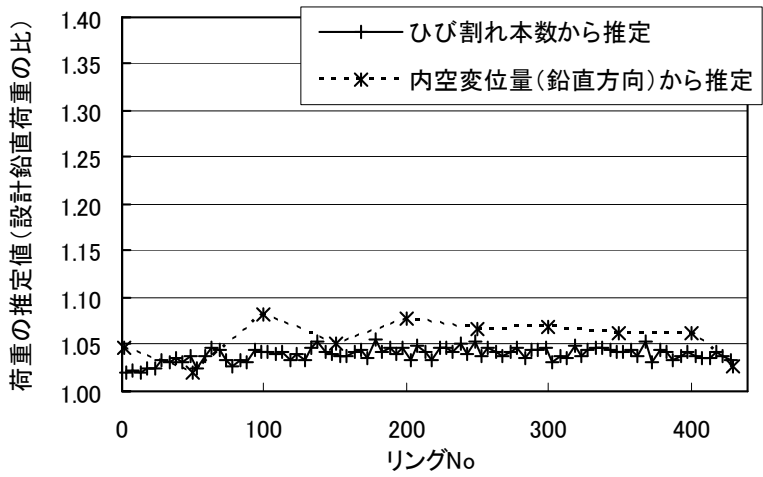

図-26 荷重の推定結果 : Ks1トンネル

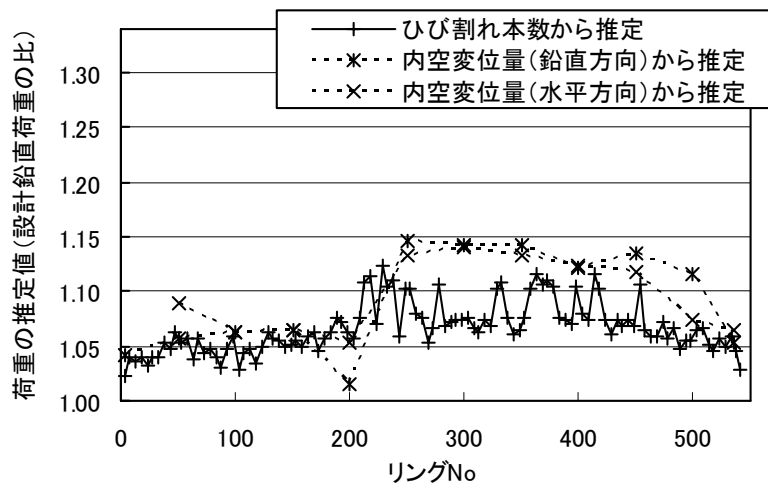

図-27 荷重の推定結果 : Ks2トンネル(区間A)

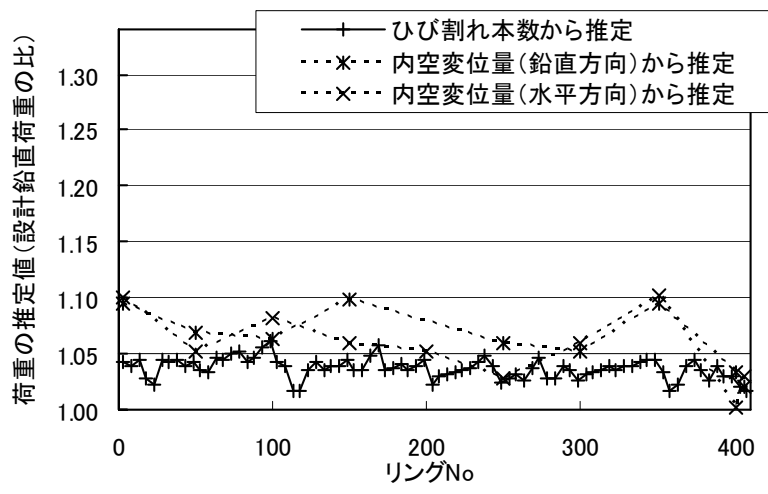

図-28 荷重の推定結果 : Ks2トンネル(区間B)

いるのは，トンネル内の気温が 1 年間で $20^{\circ} \mathrm{C}$ 程度変動し， 温度変化により材料の体積変化が生じ，トンネル径が伸 縮するためである.

以上のことから，図-24に示したように現在の荷重の 推定結果をトンネルの経年数と変動荷重の関係として, 線形補間し将来の荷重の変動量を推定することとした.

先の検討事例で，各トンネルの現在の推定荷重をひび 割れからの推定結果を用いて整理すると表-6のようにな る.このうち, 最大值を示すKeトンネルの結果から, 点検間隔である6年間の変動量を評価すると 0.04 程度 $(=0.0071 /$ 年 $\times 6$ 年，設計鈆直荷重の 1.04 倍 $)$ となる。変 動荷重が設計荷重の1.04倍程度の時の発生断面力から応 力度を算定すると許容応力度程度となった. そのため, 荷重が比較的早く変動した場合でも，6年に1回の点検で, 兆候を把握し，対策を行うことで，トンネルを健全な状

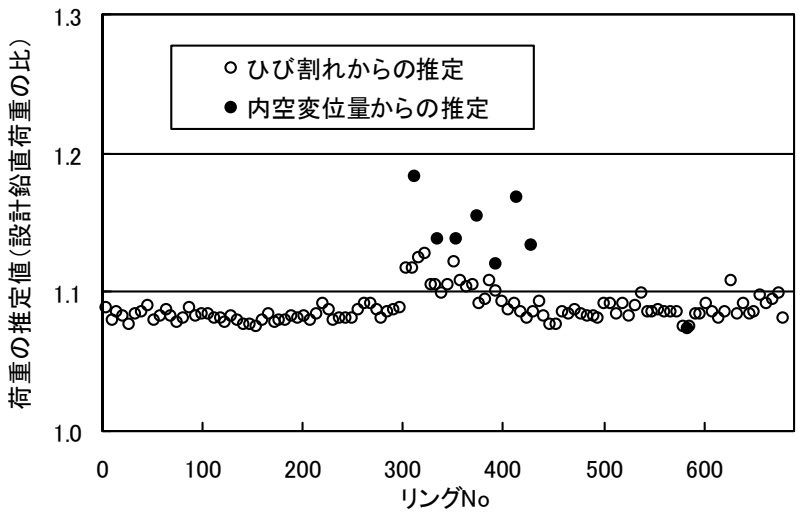

図-29 荷重の推定結果 : Mトンネル

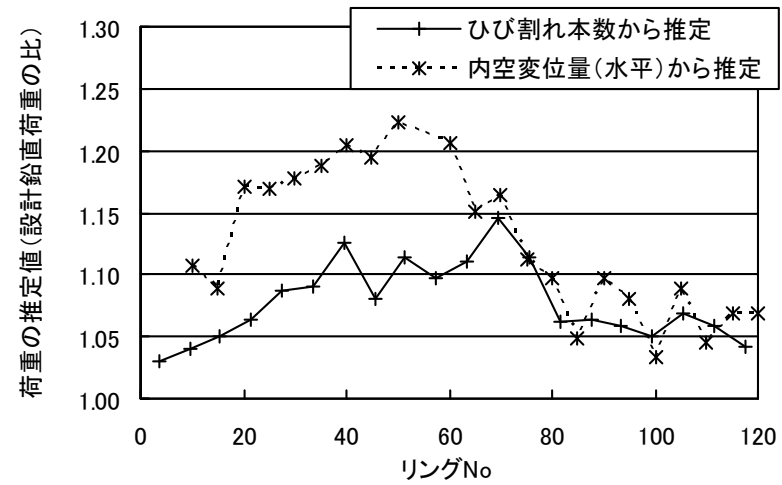

図-30 荷重の推定結果 : Keトンネル

変動荷重 線形関係とした場合の推定

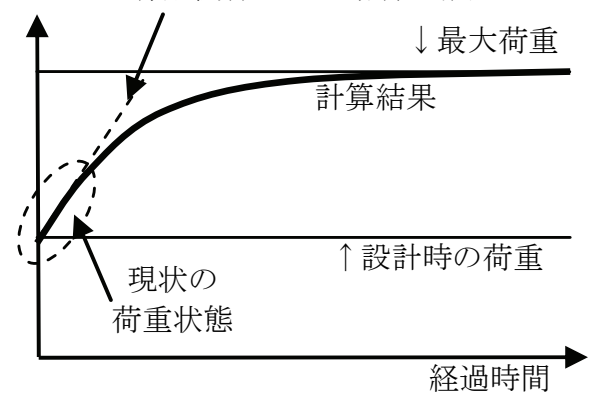

図-31 土水連成FEMによる変動荷重の計算結果のイメージ

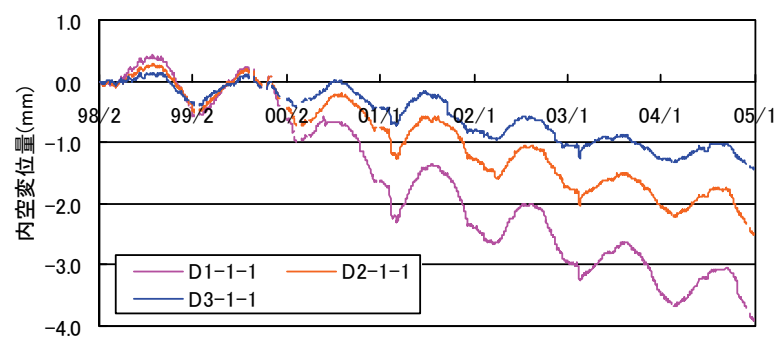

図-32 Mトンネルの内空変位の経時変化

態で維持することが可能と判断した.

また，本検討の荷重の推定方法と予測方法を用いるこ とで，将来の荷重状態および而荷性能を予測することも 可能となり，今後の効果的な対策を検討寸るための有効 な手法になると考えられる. 
表-6 変動荷重の推定結果と進行速度

\begin{tabular}{|l|c|rrr|rr|}
\hline & 経年数 & 変動荷重の推定結果変動荷重の進行速度炎 \\
\hline Mトンネル & 24 & 1.10 & $\sim 1.15$ 程度 & 0.0042 & $\sim$ & 0.0063 \\
\hline Ks1トンネル & 24 & 1.04 & 程度 & 0.0017 & \\
\hline Ks2トンネル & 22 & 1.04 & $\sim 1.12$ 程度 & 0.0018 & $\sim$ & 0.0055 \\
\hline Keトンネル & 21 & 1.05 & $\sim 1.15$ 程度 & 0.0024 & $\sim$ & 0.0071 \\
\hline
\end{tabular}

※「(変動荷重の推定結果-1.0) / 経年数」

\section{(4) まとめ}

荷重の変動に対する検討結果をまとめると以下のよう になる。

1)現場で簡易に計測可能な内空変位とひび割れ本数から 現在の荷重状態を推定することが可能となった.

2)推定された変動荷重の量からトンネルの耐荷性能を評 価することができる.

3)荷重の推定には誤差を含むことから，高精度な計測な どによる経時変化を把握することも必要である.

4)6年に1回の点検で，荷重の変動によるトンネルの耐荷 性能に影響を与える可能性はないと考えられる.

5)将来の荷重を推定し，耐荷性能を評価することができ るため, 計画的な維持管理の実施に対しても有効な手法 と考えられる.

なお，本検討は，圧密による変動荷重を対象としたも のであるが，地下水位の変動など他の変動荷重の要因に 対しても，変動荷重のメカニズムに応じて，同様の評価 を行うことが可能と考えられる.

\section{6. 健全度の簡易評価手法の検討}

\section{(1) 現状と課題}

従来，洞道内部点検結果から詳細点検の要否を判定す る基準は，一般的なコンクリート構造における劣化を対 象として設定されていた。 しかし，地中送電用シールド トンネルでは，而荷性能を満足すればある程度の劣化は 許容が可能である.また，荷重の変動は，変動が生じた 場合の影響が非常に大きいため，早期に発見し，対応し なければならない.

そこで，本研究で見直したトンネル維持管理のサイク ルにおける二次点検結果から詳細点検の要否の判定を行 う基準について検討した。

\section{（2）検討方法}

検討は，既設のシールドトンネルの構造条件を用いて， トンネル径や腐食状況，変動荷重の大きさなどのパラメ 一ターを変えた構造計算を実施し，それぞれの耐荷性能 を評価し，判定基準へ反映させることとした．構造計算 は，先に示した非線形のはりーばねモデル計算法を用い ている.
表-7 構造計算の対象としたトンネルの条件

\begin{tabular}{|c|c|c|c|c|}
\hline & 土被り & トンネル & セグメント \\
\cline { 4 - 5 } & & 外径 & 幅 & 厚さ \\
\hline Tトンネル & $13.0 \mathrm{~m}$ & $2.40 \mathrm{~m}$ & $0.75 \mathrm{~m}$ & $0.20 \mathrm{~m}$ \\
\hline $\mathrm{M}$ トンネル & $13.8 \mathrm{~m}$ & $4.00 \mathrm{~m}$ & $0.90 \mathrm{~m}$ & $0.25 \mathrm{~m}$ \\
\hline $\mathrm{K}$ トンネル & $21.6 \mathrm{~m}$ & $5.65 \mathrm{~m}$ & $0.90 \mathrm{~m}$ & $0.30 \mathrm{~m}$ \\
\hline
\end{tabular}

\section{a) 検討ケース}

検討では，地中送電用シールドトンネルの径の大きさ を考慮し，表-7に示すトンネル径の異なる3トンネルを 対象とした.

健全度低下の要因としては，先に述べたように部材劣 化と変動荷重を対象とした。 なお，実際のトンネルでは， 部材劣化と変動荷重が同時に生じることも考えられる. しかし，2つの健全度低下が同時に生じる確率は低いと 考えられる。.また，而荷性能が問題となる経過時間は， 変動荷重に比べ部材劣化の進行速度は遅くなる傾向にあ る. そのため, 変動荷重と部材劣化は分けて評価し, 詳 細点検の結果による検討の際に必要に応じて2つの健全 度低下の要因を同時に扱う方針とした。

而荷性能の評価は，使用限界状態を基本としている. ただし，既設のトンネルは許容応力度法で設計されてお り，さらに維持管理では健全度の低下を早期に発見し計 画的に対策を実施することが重要であることから，使用 限界状態の応力制限值を許容応力度相当とした。 また, 非線形の計算を実施し，後に示す部材の劣化をモデル化 した個所では断面力が小さく而荷性能は問題ないものの 変形が大きくなることが考えられた．そこで，変形量に 関する限界值は，文献3)の常時性能に照査例に示されて いる，トンネル内径： $D_{i} / 150$ ( $D_{i}$ はトンネル内径)，セ グメント継手の目開き量 : $2.0 \mathrm{~mm}$, リング継手の目違い 量 : 3.0mmとして照査した.

\section{b) 変動荷重のモデル化}

荷重の変動は，圧密による場合を想定して設定する. セグメントの設計では, 荷重の大きさも重要であるが, 鉛直荷重と水平荷重との比が大きく影響する，そのため， 変動荷重は，表-4に示した土/水連成FEM計算による計 算例を参考に鉛直荷重のみを設計荷重の1.3倍として考 慮方法と同様に行った. 照査は, 変動荷重の構造計算の 全荷重増分ステップ（200ステップ）に対して行い，照 査結果を満足しなくなる変動荷重およびセグメントの状 態について整理した.

\section{c) 部材劣化のモデル化}

セグメント本体は，実際のトンネルで鉄筋が腐食し被 りコンクリートがはく落するような事例は，極端に鉄筋 の被りが薄く製造に問題があったと考えられる一部のセ グメントを除き，ほとんどみられない，そのため，セグ メント本体の劣化は, 最も危険な状態としてセグメント 


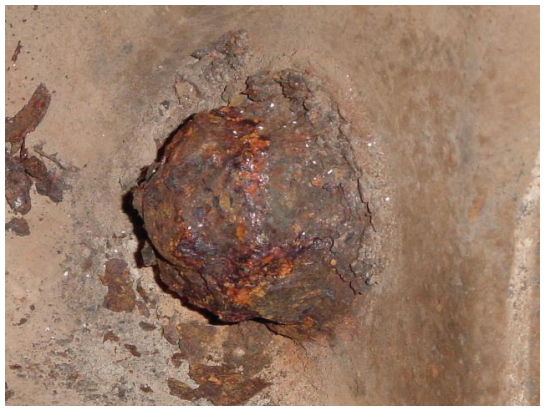

図-33 腐食が激しいボルトの例

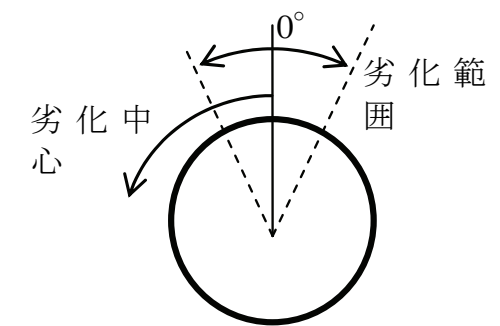

図-34 部材劣化の検討における劣化範囲の設定方法

厚さは変えず鉄筋の有効断面積が60\%程度になった状態 とした.一方，継手は，継手の調査結果から，ボルトの 軸力は大きくないが，継手の締結の効果は，腐食が進行 してもある程度は期待できる。しかし，図-33に示すよ うにボルトの頭部やナット部が著しく腐食し，一部で脱 落している事例も報告されている，そこで，継手の腐食 は，ボルトの頭部などが脱落し，セグメント継手の回転 剛性やリング継手のせん断岡性が期待できないものとし てモデル化した.

これらの腐食は，図-34に示すように，トンネル横断 面方向の一部を中心とする範囲に劣化が生じるとして, 劣化中心位置をトンネル天端から下端まで, 劣化の範囲 を0 から $180^{\circ}$ までの組合わせの劣化状態を想定した.

\section{（3）変動荷重の検討結果}

\section{a) 変動荷重によるセグメントの状態}

二次点検時や簡易な計測で得られるデータとして，ひ び割れや内空変位量に着目し，構造計算結果の分析を行 った．変動荷重と内空変位量との関係は，図-35に示す 例のように，荷重の変動とともに内空変位量が大きくな り，途中にいくつか変形が大きくなる個所が見られる.

これらは，トンネルの竣工検査や文献1)で変形量照査の 基準としている $D_{i} / 150 や D_{i} / 100$ （ $D_{i}$ はトンネル内径）に近 くなっている.

而荷性能の照査は，設計荷重から変動荷重の最大值最 終值までの全計算ケースに対して行った。照査は，限界 状態設計法で行うように「応答值 $S_{d} /$ 限界值 $\left.R_{d}\right\rfloor$ とし, 1.0 以下であれば，限界值とした応力度を満足すると判断さ れる. 図-36は，セグメント本体の曲げモーメントに対 する而荷性能について, 許容応力度を限界值として照査

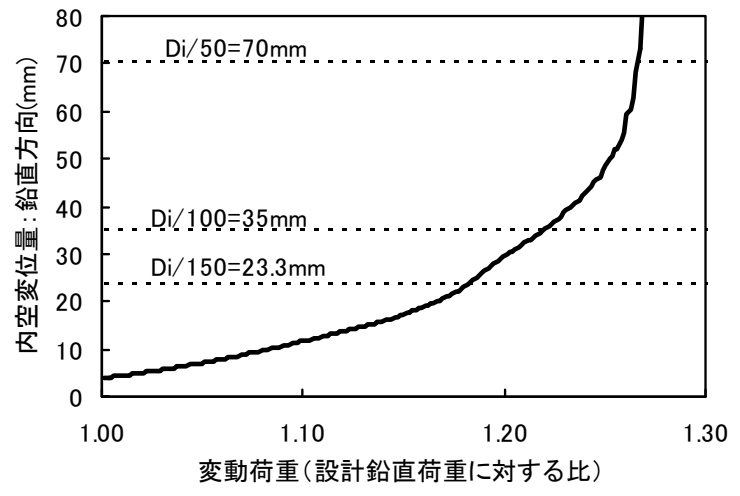

図-35 変動荷重と内空変位量の関係の例

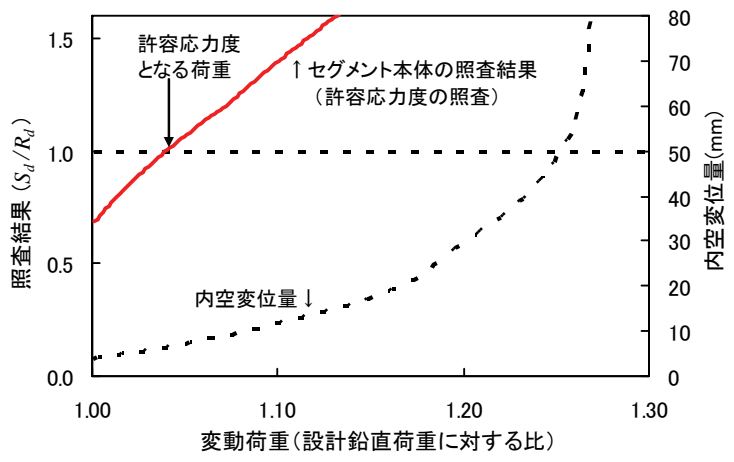

図-36 変動荷重と照査結果の関係の例

Mトンネル，セグメント本体の曲げモーメントの照査

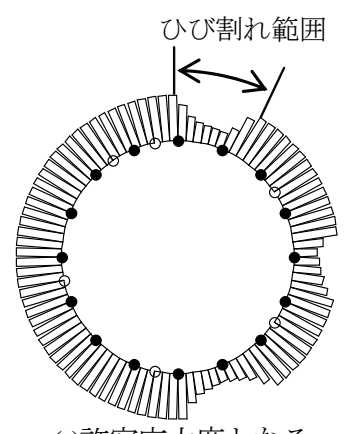

(a)許容応力度となる 荷重状態

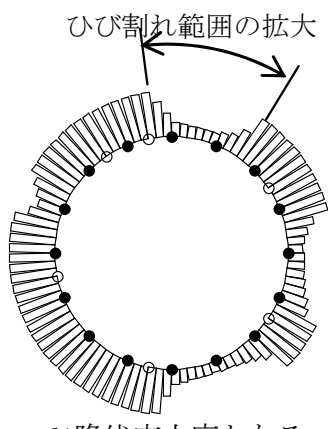

(b)降伏応力度となる 荷重状態
図-37 変動荷重によるトンネルの軸方向ひび割れ状況の例

した結果を，変動荷重との関係として整理した例である。 変動荷重の増加に伴い照査結果が大きくなり, 安全性が 低下し，図示した例では，変動荷重が1.04程度で許容応 力度となっている．これと同様に，セグメント継手やリ ング継手などの照查も行い, 許容応力度になるときの変 動荷重と, その時のひび割れ本数について整理した.

図-37は，セグメント本体の応力度が許容応力度と降 伏応力度となる荷重状態となる時の非線形の構造計算に おけるセグメント本体の岡性をトンネル円周上の分布と して整理した例である。これより，凹の部分で岡性が低 下，つまりセグメントにひび割れが生じていると見るこ とができる．これより，許容応力度程度の荷重状態でも， トンネル天端や下端，スプリングライン付近にひび割れ 
表-8 許容応力度となる時の変動荷重とひび割れ本数の計算結果

\begin{tabular}{|c|c|c|}
\hline & 変動荷重※ & ひび割れ本数 \\
\hline Tトンネル & 1.03 & 2.9本 \\
\hline Mトンネル & 1.07 & 5.5本 \\
\hline Kトンネル & 1.06 & 7.6本 \\
\hline
\end{tabular}

※設計鉛直荷重に対する比

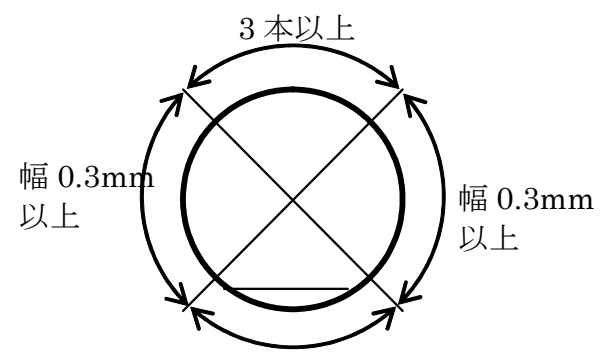

図-38＼cjkstart変動荷重による軸方向ひび割れの判断基準

\begin{tabular}{|c|c|c|c|c|c|c|c|c|}
\hline 凡例 & 은 & 0 & 8 & 0 & 은 & $\diamond$ & 0 & 0 \\
\hline 劣化の中心位置 & 0.0 & 11.3 & 22.5 & 33.8 & 45.0 & 56.3 & 67.5 & 90.0 \\
\hline 凡例 & 2 으 & 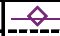 & 9 & 20 & 으 & 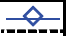 & $=$ & \\
\hline & & & & & & & 180.0 & \\
\hline
\end{tabular}

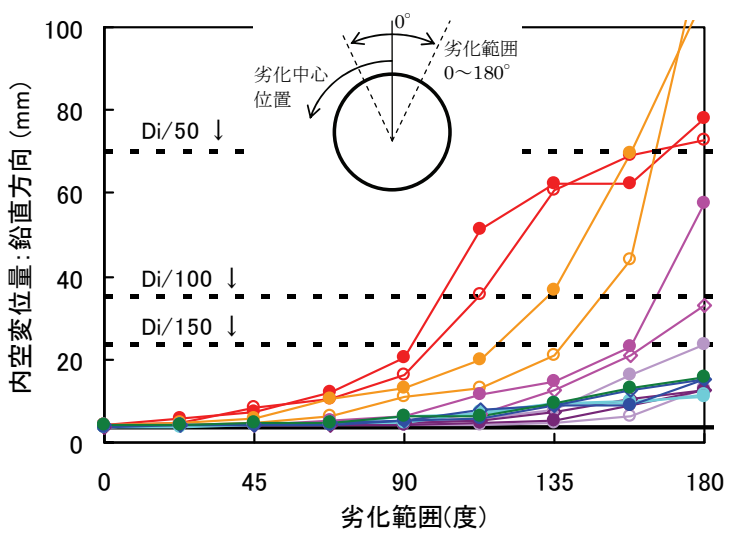

図-39 劣化の中心位置および範囲と内空変位量との関係

が見られる.さらに降伏応力度程度の荷重状態となると， ひび割れの範囲が拡大していることが確認できる，その ため，ひび割れの範囲から，簡易にトンネルの耐荷性能 を評価することが可能と考えられる。

\section{b) 点検基準の検討}

構造計算の結果から，点検基準にはひび割れ範囲を用 いることとした．ただし，通常，トンネル下端には点検 用通路のためのインバートコンクリートが打設されてい ることから，ひび割れの観察は限定される．また，スプ リングライン付近は，トンネル外側に変形寸る負曲げの 状態であり，ひび割れがトンネル外面に発生し観察がで きない，そのため，点検における而荷性能の評価は，卜 ンネル天端付近ののひび割れ範囲で行うこととした.

二次点検では，点検と結果の整理，評価を簡易に実施 できることが望ましい，また，東京電力（株）では，従 来から, 洞道内部点検においてひび割れの本数を整理し ている.このような状況から, 点検基準はひび割れ本数 として示寸ことが望ましいと判断した。構造計算結果か

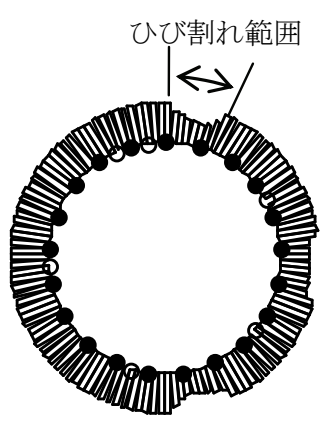

(a)劣化の範囲 $0^{\circ}$

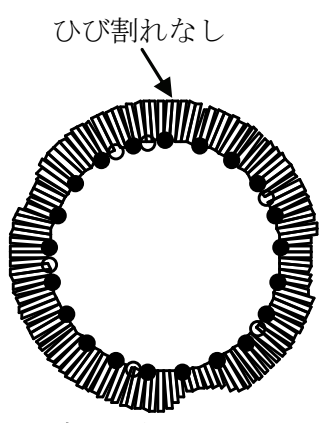

(b)劣化の範囲 17
図-40 劣化の範囲と軸方向ひび割れの関係の例 (劣化の中心位置 $0^{\circ}$ )

表-9 部材劣化に関する構造計算のケース

\begin{tabular}{|l|c|c|c|}
\hline & $\begin{array}{c}\text { 劣化の } \\
\text { 中心位置 }\end{array}$ & $\begin{array}{c}\text { 劣化の } \\
\text { 範囲 }\end{array}$ & $\begin{array}{c}\text { 組合せ } \\
\text { ケース数 }\end{array}$ \\
\hline Tトンネル & 12 & 7 & 84 \\
\hline Mトンネル & 15 & 9 & 135 \\
\hline Kトンネル & 22 & 12 & 264 \\
\hline \multicolumn{2}{r}{} & 合計 & 483 \\
\cline { 3 - 4 }
\end{tabular}

ら，ひび割れ本数は，前述のとおりセグメントのひび割 れが配力筋間隔で発生すること，および配力筋は最大で もセグメント厚さ程度の間隔で配置されていることから, 安全側に評価するため,「ひび割れ範囲 $\div$ セグメント厚 さ」として算定した.

計算および照査の結果は表-8に示すようになり, 許容 応力度となるひび割れ本数が3〜8本程度となった。 これ より，二次点検は，1リングあたり3本のトンネル軸方向 ひび割れを詳細点検の要否の判定基準とした. この判定 基準は，トンネル天端から横断面方向の左右 $45^{\circ}$ の範囲 に発生するひび割れを対象に適用する．トンネル下端付 近は歩床コンクリートがあるため, ひび割れ発生の確認 が十分にできない．また，スプリングライン付近は，構 造計算上，トンネル内面に曲げひび割れが発生しない. しかし，予測しない荷重が生じる場合も考えられること から，文献21)のひび割れ幅算定式から，鉄筋の応力度 が許容応力度程度となる幅0.3mm以上のひび割れを詳細 点検の要否の判定基準とした. これらの判定基準を簡単 に示寸と図-38のようになる。

ただし，これらの基準は，セグメントが千鳥組で施工 されていることを前提としている．継手位置がトンネル 軸方向に同一位置となるいも継ぎの場合は, 継手で変形 が進行しひび割れの範囲が小さくなる傾向にある，その ため, いも継ぎの場合には, 内空変位量の計測など他の 点検結果も併用して判定する必要がある.

\section{（4）部材劣化の検討結果}

a) 部材劣化によるセグメントの状態

劣化の中心位置と範囲の組合わせによる内空変位量の 
表-10 而渮性能※を超える劣化数量（2リングあたり）

\begin{tabular}{|c|c|c|c|c|c|c|c|c|c|}
\hline \multirow[b]{2}{*}{ 計算ケース } & \multicolumn{3}{|c|}{ トンネル天端 } & \multicolumn{3}{|c|}{ スプリングライン } & \multicolumn{3}{|c|}{ トンネル下端 } \\
\hline & $\begin{array}{l}\text { セ } \\
ク ゙ ~ \\
x \\
ン \\
\text { ト } \\
\text { 本 } \\
\text { 体 }\end{array}$ & $\begin{array}{l}セ \\
\text { グ } \\
\text { メ } \\
ン \\
\text { ト } \\
\text { 継 } \\
\text { 手 }\end{array}$ & $\begin{array}{l}\text { リ } \\
\text { ン } \\
\text { グ } \\
\text { 継 } \\
\text { 手 }\end{array}$ & $\begin{array}{l}\text { セ } \\
ク ゙ ~ \\
メ \\
ン \\
\text { ト } \\
\text { 本 } \\
\text { 体 }\end{array}$ & $\begin{array}{l}\text { セ } \\
ク ゙ ~ \\
\searrow \\
ン \\
\text { ト } \\
\text { 継 } \\
\text { 手 }\end{array}$ & $\begin{array}{l}\text { リ } \\
\text { ン } \\
\text { グ } \\
\text { 継 } \\
\text { 手 }\end{array}$ & $\begin{array}{l}\text { セ } \\
ク ゙ \\
\searrow \\
ン \\
\text { ト } \\
\text { 本 } \\
\text { 体 }\end{array}$ & $\begin{array}{c}セ \\
\text { グ } \\
\text { メ } \\
\text { ン } \\
\text { 卜 } \\
\text { 継 } \\
\text { 手 }\end{array}$ & $\begin{array}{l}\text { リ } \\
\text { ン } \\
\text { グ } \\
\text { 継 } \\
\text { 手 }\end{array}$ \\
\hline Tトンネル & $1 / 12$ & $1 / 12$ & $1 / 11$ & $2 / 12$ & $1 / 12$ & $1 / 11$ & $1 / 12$ & $1 / 12$ & $1 / 11$ \\
\hline Mトンネル & $4 / 12$ & $3 / 12$ & $3 / 16$ & $4 / 12$ & $3 / 12$ & $5 / 16$ & $5 / 12$ & $4 / 12$ & $6 / 16$ \\
\hline Kトンネル & $1 / 12$ & $1 / 12$ & $1 / 21$ & $1 / 12$ & $1 / 12$ & $1 / 21$ & $1 / 12$ & $1 / 12$ & $1 / 21$ \\
\hline
\end{tabular}

※材料の限界值を許容応力度とした而荷性能

※表中の数值は，「劣化部材数 2 リングの各部材数」

関係を図-39に示す.これより，トンネル天端付近を中 心に劣化する場合がトンネルの変形が最も大きくなる傾 向にあることがわかる。これは，トンネル天端位置は曲 げモーメントが大きくなる個所であり，さらに，Kセグ メントが配置され，他の個所に比べセグメントの剛性が 小さくなるためである. これより, 部材劣化の場合も卜 ンネル天端位置に最も着目して点検寸る必要があると考 えられる.

次に，劣化中心位置がトンネル天端位置 $\left(0^{\circ}\right)$ の場 合における劣化範囲の拡大によるひび割れ状況の例を 図-40に示す．図-36と同样に凹部分がひび割れ範囲であ る.これより，劣化の範囲が広がると計算上のひび割れ 範囲が小さくなる.これは, セグメント継手やリング継 手が劣化し, 剛性（回転ばね定数やせん断ばね定数）が 0となることで, 継手で大きな変形が発生しセグメント 本体の断面力が小さくなるためである. よって, 部材劣 化の場合は, 劣化が進行すると曲げひび割れの範囲が広 がるとは言えず, 詳細点検の要否の判定基準として適し ていないと考えられる.

\section{b) 点検基準の検討}

検討対象としたトンネルに対し, 劣化中心位置と範囲 の組合わせとして表-9に示すケースの構造計算と照査を 行い, 劣化数量から詳細点検の要否の判定基淮を検討寸 ることとした. ここで，各トンネルのケース数が異なる のは, 劣化中心および劣化範囲をセグメント継手やリン グ継手の位置を基準に変更しているためである.

構造計算と照査の結果から, 而荷性能として許容応力 度を超える最小の劣化範囲および劣化数量を整理した結 果を表-10に示す. 表は, 許容応力度を超える2リング当 たりの劣化部材数を示している. また，劣化位置による 差異を見るため, 劣化中心位置をトンネル天端, スプリ ングライン, トンネル下端の3種類に分類して示した. この結果から, 最小で1リング当たり1個所の部材が激し く劣化すると許容応力度を超える可能性のあることがわ かる．なお，劣化中心位置により判定基準を変えるほど，
許容応力度を超える最小の部材数の大きな差異は見られ ない.

そこで，部材劣化の場合には，劣化位置によらずセグ メント本体は鉄筋が $60 \%$ 程度の有効断面積に減少，セグ メント継手とリング継手はボルトが脱落するような激し い腐食が1リング当たり1個所見られる場合を詳細点検の 要否を判定する基淮とした.

\section{（5）検討結果と点検基準のまとめ}

検討の結果，変動荷重はトンネル天端位置のひび割れ 本数, 部材劣化の場合は劣化の数量に着目して, 而荷性 能に着目した簡易評価を行うこととした.

これらの結果を用いて, 二次点検における詳細点検の 要否の判定基準を設定した。 点検基準を超えたトンネル は詳細点検を実施する，詳細点検は，現状や将来の耐荷 性能を詳細に検討し，その結果によって，管理を重点監 視や補修, 補強などの対策に移行する。また, 明らかに 漏水中の塩分が多く劣化などの変状の進行が明らかな卜 ンネルは, 点検基準の判定によらず重点監視などの対策 について検討する.

ここで, 二次点検の結果の評価において, 健全度低下 の要因を選定するための, 明確な判断基準を設定するこ とは困難であった，そのため，腐食が軽微でトンネル軸 方向のひび割れのみが多い場合は変動荷重, 腐食個所が 多くひび割れが少ない場合は部材劣化として判断するこ とを目安とした. しかし，上記の考え方でも判断が困難 な場合には, 変動荷重と部材劣化の両方の基準で評価し, 詳細点検時に再検討寸ることとしている.

これより, 従来は定性的であり, 技術者の経験に大き く頼っていた健全度の評価を, ひび割れ本数や劣化数量 の簡単な数量で明示することで, 経験が少ない点検者で も容易に健全度が判断でき, 健全度評価の高精度化を実 現することができた. 
表-11 地中送電ケーブル用トンネルの要求性能や点検方針の検討結果

\begin{tabular}{|c|c|c|}
\hline 性能 & 性能の整理の結果 & 点検の方針 \\
\hline 而荷性能 & 不可欠な性能 & $\begin{array}{c}\text { ひび割れ本数, 劣化箇所数から } \\
\text { 而荷性能を定量的に評価 }\end{array}$ \\
\hline 変形性能 & $\begin{array}{c}\text { 送電に支障がなく，明らかな異 } \\
\text { 常な変位でなければ許容可. }\end{array}$ & $\begin{array}{c}\text { 一次点検などで } \\
\text { 明らかな異常を監視 } \\
\end{array}$ \\
\hline 而对久性能 & $\begin{array}{c}\text { 而付荷性能が担保される範囲で許 } \\
\text { 容可. }\end{array}$ & 耐荷性能の基淮から判定 \\
\hline 止水性能 & $\begin{array}{l}\text { 送電機能の支障, 第三者への影 } \\
\text { 響がない軽微な漏水は許容可. }\end{array}$ & $\begin{array}{c}\text { 一次点検などで } \\
\text { 明らかな異常を監視 }\end{array}$ \\
\hline
\end{tabular}

\section{7. おわりに}

地中送電用シールドトンネルの要求性能や点検方針の 結果を整理すると表-11となる. 本研究の結果から, 地 中送電用シールドトンネルの要求性能から而荷性能に着 目した点検基準を設定し，見直した維持管理サイクルを 標準化し，合理的な維持管理へ発展させることができた. 特に点検基準をひび割れ本数など定量的な指標とするこ とで，健全度の評価の高精度化を実現した。また，シー ルドトンネルの健全度低下の要因として, 部材劣化に加 え，トンネルに対してリスクが高い荷重変動も対象とし， 而荷性能を評価するための方法を示すなど，本研究の要 素技術は，詳細な而荷性能の評価や将来の維持管理計画 にも適用可能と考えられる.

本検討は，地中送電用シールドトンネルを対象に検討 を行った. 一方，他の用途のトンネルにおいても，要求 性能の整理や要求性能を満足する指標の設定など，同様 の方法により，維持管理の合理化が可能と考えられる.

現在は，本研究で得られた知見と簡易判定基準を用い て維持管理を実施している。一次点検においても，本研 究の成果を用いて，たとえばひび割れの進展は範囲の拡 大に着目して行うなど，さらに効率的な点検方法につい て検討を行っている，また，詳細点検結果に基づくトン ネルの健全度の評価でも, 荷重の推定や鋼材の腐食の結 果を用いて，検討を実施している.

今後は，本研究の成果を，点検で得られたデータから 検証し, 効果的な維持管理を推進するため, 環境条件な どによる点検間隔の見直しなど，さらに検討を進める予 定である.

\section{参考文献}

1) (社)土木学会 : トンネルライブラリー第14号 トンネ ルの維持管理, pp.14-23, 2005.

2) (社)土木学会：2007年制定 コンクリート標準示方書 [維持管理編]，pp.5-8, 2007.

3) (社)日本トンネル技術協会：シールドトンネルを対 象とした性能照査型設計法のガイドライン, 2003.

4) 吉本正浩, 阿南健一, 大塚正博, 小泉淳：地中送電 用シールドトンネルの性能規定と限界状態設計法に よる照査, 土木学会論文集, No.764/III-67, pp.255-
274, 2004.

5) 落合孝雄, 円谷喜只, 阪井田修, 田中榮一：電力洞 道改修工事における新しい内巻き補強工法, トンネ ルと地下，第30巻1号, pp.46-52, 1999.

6) 山口高嶺, 田村隆志, 森島弘吉 : 東京トンネルの変 状と対策について, 土木学会第59回年次学術講演会 4-131, pp.261-262, 2004.

7) 大塚努, 堀健三, 山中耕太郎：千代田線隅田川シー ルドトンネル二次巻き工事の施工, 土木学会第61回 年次学術講演会 6-006, pp.11-12, 2006.

8) 有泉毅：軟弱粘性土地盤中のシールドトンネルに働 く長期荷重に関する研究, 東京工業大学学位論文, 2006.

9) 有泉毅, 五十嵐廣昌, 金子俊輔, 永谷英基, 山崎剛, 日下部治 : 周辺地盤の圧密沈下に伴う既設シールド トンネル作用荷重の変化メカニズム, 土木学会論文 集, No.750/III-65, pp.115-134, 2003.

10) 山崎剛, 有泉毅, 五十嵐廣昌: 連載講座 シールド掘 進に伴う地盤変造入門(14) シールド新時代に向けて （その2）一維持管理における新たな技術的課題一, トンネルと地下, Vol35, No.1, pp.65-71, 2004.

11) 斉藤正幸, 古田勝, 山本稔: 沖積層地盤に構築した シールドトンネルの変形に関する考察, トンネル工 学研究発表会論文・報告集, 第4巻, pp.55-62, 1994.

12) (社)土木学会 : トンネルライブラリー第14号 トンネ ルの維持管理, p.43, 2005.

13) (社)土木学会 : 2007年制定 コンクリート標準示方書 [維持管理編］, pp.12-22, 2007.

14) (社)土木学会：トンネルライブラリー第14号 トンネ ルの維持管理, pp.38-44, 2005.

15) たとえば，(社)日本コンクリート工学協会 : コンクリ 一トのひびわれ調査, 補修・補強指針, 1987.

16) (社)土木学会：2007年制定 コンクリート標準示方書 [維持管理編］, p.82,101，2007.

17）たとえば, 中川貴之, 瀬下雄一, 堤知明, 安田登 : 塩害環境下にあるRC構造物の維持管理支援システム の開発, コンクリート工学, Vol.40, No.3, pp.53-58, 2002.

18) (社)土木学会 : 2006年制定 トンネル標準示方書 [シ ールド工法］・同解説, pp.42-47, 2006.

19）金子俊輔, 有泉毅, 山崎剛, 塩冶幸男: 軟弱粘性土 の圧密に伴って発生するトンネル覆工作用土圧につ いて，地下空間シンポジウム論文・報告集，Vol.9, pp.227-234, 2004.

20) 村上博智, 小泉淳 : シールド工事用セグメントのセ グメント継手の挙動について, 土木学会論文報告集, 第296号, pp.73-86, 1980.

21) (社)土木学会 : 2006年制定 トンネル標準示方書 [シ 
ールド工法］・同解説，pp.287-289， 2006.

22) Branson, D. E.: Deflections of Concrete Structures, McGraw-Hill, 1977.

23) (社)土木学会：2006年制定 トンネル標準示方書 [シ ールド工法］・同解説「第5編限界状態設計法」につ いての条文制定資料と設計計算例，p.23，2006.

24) 中村敏一, 石村彰生, 西尾誠高, 湯浅康尊, 増野正
男：RCセグメントの水密性に関する評価について, トンネル工学研究論文・報告集, 第11巻, pp.339-344, 2001.

\section{STUDY OF MAINTENANCE OF SHIELD TUNNEL FOR UNDERGROUND TRANSMISSION}

\section{Yukio ENYA, Kenichi ANAN, Masahiro OOTSUKA and Atsushi KOIZUMI}

In this report, the methods of management and maintenance of the shield tunnel for underground transmission cables were studied. These studies are based on the Performance-Based Design concept, and focused on the load bearing capacity of a tunnel. First, the maintenance cycle were reviewed for improving efficiency and effectiveness by considering the present inspection period and the soundness of a tunnel. For reviewing the maintenance cycle, the changes of load bearing capacity due to the changes of external loads and soundness caused by aged deterioration of segmental joints, and the criteria and the standardization of inspection results were investigated. Moreover, the corrosion speed and the fastening force of a segmental joint were inspected. The changes of external loads were assumed and used them for evaluating the load bearing capacity of a tunnel. The standard of an inspection was also reviewed based on the standards of deterioration materials, and the load bearing capacity obtained by structural calculation. Based on results of all investigation, the rational management and maintenance methods of a shield tunnel and the applying methods for existing tunnels are proposed. 